\title{
ARTICLE
}

Chronic myelogenous leukemia

\section{Specific, targetable interactions with the microenvironment influence imatinib-resistant chronic myeloid leukemia}

\author{
Rahul Kumar ${ }^{1}$ - Raquel S. Pereira ${ }^{1} \cdot$ Costanza Zanetti $^{1} \cdot$ Valentina R. Minciacchi $^{1} \cdot$ Maximilian Merten $^{1}$. \\ Melanie Meister ${ }^{1}$ Julian Niemann ${ }^{1} \cdot$ Marina S. Dietz $^{2} \cdot$ Nina Rüssel $^{1} \cdot$ Frank Schnütgen $^{3,4} \cdot$ Minori Tamai $^{5}$. \\ Koshi Akahane ${ }^{5}$. Takeshi Inukai ${ }^{5}$. Thomas Oellerich ${ }^{3,4,6,7}$. Hans Michael Kvasnicka ${ }^{8}$. Heike Pfeifer ${ }^{3}$. \\ Franck E. Nicolini ${ }^{9} \cdot$ Mike Heilemann $^{2} \cdot$ Richard A. Van Etten ${ }^{10}$ - Daniela S. Krause ${ }^{1,3,4,6,7}$
}

Received: 16 April 2020 / Revised: 29 April 2020 / Accepted: 11 May 2020 / Published online: 21 May 2020

(c) The Author(s) 2020. This article is published with open access

\begin{abstract}
Therapy resistance in leukemia may be due to cancer cell-intrinsic and/or -extrinsic mechanisms. Mutations within $B C R-A B L 1$, the oncogene giving rise to chronic myeloid leukemia (CML), lead to resistance to tyrosine kinase inhibitors (TKI), and some are associated with clinically more aggressive disease and worse outcome. Using the retroviral transduction/transplantation model of CML and human cell lines we faithfully recapitulate accelerated disease course in TKI resistance. We show in various models, that murine and human imatinib-resistant leukemia cells positive for the oncogene $B C R-A B L 1^{T 315 I}$ differ from $B C R-A B L 1$ native $(B C R-A B L 1)$ cells with regards to niche location and specific niche interactions. We implicate a pathway via integrin $\beta 3$, integrin-linked kinase (ILK) and its role in deposition of the extracellular matrix (ECM) protein fibronectin as causative of these differences. We demonstrate a trend towards a reduced BCR-ABL1 ${ }^{\mathrm{T} 315 \mathrm{I}}$ tumor burden and significantly prolonged survival of mice with BCR-ABL1 ${ }^{\mathrm{T} 315 \mathrm{I}+} \mathrm{CML}$ treated with fibronectin or an ILK inhibitor in xenogeneic and syngeneic murine transplantation models, respectively. These data suggest that interactions with ECM proteins via the integrin $\beta 3 /$ ILK-mediated signaling pathway in BCR-ABL1 ${ }^{\mathrm{T} 315 \mathrm{I}+}$ cells differentially and specifically influence leukemia progression. Niche targeting via modulation of the ECM may be a feasible therapeutic approach to consider in this setting.
\end{abstract}

\section{Introduction}

Resistance to cancer treatments may be due to cancer cellintrinsic mechanisms, such as alteration of the drug target,

These authors contributed equally: Raquel S. Pereira, Costanza Zanetti

Supplementary information The online version of this article (https:// doi.org/10.1038/s41375-020-0866-1) contains supplementary material, which is available to authorized users.

Daniela S. Krause

Krause@gsh.uni-frankfurt.de

1 Georg-Speyer-Haus, Institute for Tumor Biology and Experimental Therapy, 60596 Frankfurt am Main, Germany

2 Institute for Physical and Theoretical Chemistry, GoetheUniversity Frankfurt, Frankfurt am Main, Germany

3 Department of Internal Medicine, Hematology/Oncology, Goethe University, Frankfurt am Main, Germany

4 Frankfurt Cancer Institute (FCI), Goethe University, Frankfurt am Main, Germany deregulation of (anti-) apoptotic pathways, drug inactivation or shuttling of the drug out of the cancer cell [1-3]. Cancer cell-extrinsic mechanisms of chemoresistance may be mediated by alterations of drug binding to plasma proteins or their catabolism or the tumor microenvironment [4]. However, whether leukemia cell-intrinsic mutations conferring resistance to therapy lead to differential interactions with the bone marrow (BM) microenvironment (BMM), a complex arrangement of various cell types, extracellular

5 Department of Pediatrics, School of Medicine, University of Yamanashi, Chuo, Japan

6 German Cancer Consortium (DKTK), Heidelberg, Germany

7 German Cancer Research Center (DKFZ), Heidelberg, Germany

8 Senckenberg Institute of Pathology, Goethe University Frankfurt, 60590 Frankfurt am Main, Germany

9 Department of Hematology and INSERM U 1052, CRCL, Centre Léon Bérard, 69373 Lyon Cedex, France

10 Chao Family Comprehensive Cancer Center, University of California, Irvine, CA 92697, USA 
matrix (ECM) proteins, and other factors [5], has not been shown.

The $B C R-A B L 1$ oncogene, generated by the translocation between chromosomes 9 and 22, results in deregulated activity of the BCR-ABL1 tyrosine kinase driving chronic myeloid leukemia (CML) at early disease stages [6]. BCRABL1 is targeted by tyrosine kinase inhibitors (TKIs) [7]. However, resistance to TKIs such as imatinib may occur due to the $B C R-A B L 1^{T 315 I}$ and other mutations [8,9]. $B C R$ $A B L 1^{T 315 I}$ arises in the ABL kinase domain interfering with binding to TKIs like imatinib and others [8, 9] accounting for $15-20 \%$ of mutations found in CML patients [10, 11]. Patients with imatinib resistance due to $\mathrm{BCR}-\mathrm{ABL} 1^{\mathrm{T}}{ }^{\mathrm{T} 15 \mathrm{I}}$ have a rapid clinical course and poor prognosis [11-13], although other mechanisms may be contributory [14]. In the case of BCR-ABL1 ${ }^{\mathrm{T} 315 \mathrm{I}}$ kinase activity does not correlate with increased transformation potency [15, 16]. Global phosphoproteome analysis of BCR-ABL1 ${ }^{\mathrm{T} 315 \mathrm{I}+}$ cells identified a unique signature of phosphosubstrates compared with cells positive for native BCR-ABL1 or other imatinibresistance conferring mutations leading to altered biological properties [15]. However, exactly how these leukemia cellintrinsic alterations might influence disease outcome, for instance via altered interactions with the BMM, has not been demonstrated.

Niche occupation in the BMM by normal hematopoietic stem and progenitor cells (HSPC) [17] or leukemic stem cells (LSC) in acute myeloid leukemia (AML) [18] depends on their maturation stage or the state of disease progression, respectively. We hypothesized that differences in clinical outcome of patients with CML due to imatinib-resistant mutations in BCR-ABL1 may correlate with LSC location in the BMM and specific interactions with the BMM. Indeed, here we show that interactions of leukemic murine and human cells with the BMM via the fibronectin/integrin $\beta 3$ / integrin-linked kinase (ILK)-mediated signaling pathway influence leukemia progression and clinical outcome in BCR-ABL1 $1^{\mathrm{T} 315 \mathrm{I}+}$ imatinib-resistant CML in vivo. Targeting these interactions may offer a beneficial, innovative, additive treatment strategy for patients with BCR$\mathrm{ABL}^{\mathrm{T} 315 \mathrm{I}+} \mathrm{CML}$, and possibly other leukemias.

\section{Materials and methods}

\section{Statistical analysis}

All statistical analyses were performed using GraphPad Prism software. Survival curves were analyzed by Kaplan-Meier-style curves and Log-rank (Mantel-Cox) or Gehan-Breslow-Wilcoxon tests. Differences between groups were assessed by student's $t$-test. When multiple hypotheses were tested, one-way ANOVA and a Tukey test were used as post-hoc test. The data were presented as mean \pm s.d. $P$ values $\leq 0.05$ were considered significant.

\section{Results}

\section{BCR-ABL1 $^{\text {T3151+ }}$ differ from BCR-ABL1 ${ }^{+}$cells with regards to diverse biological functions}

To test the location of CML-initiating cells (LIC) in the BMM, we performed in vivo confocal 2-photon microscopy of the murine calvarium. Measuring the shortest threedimensional distance to the endosteum [17], we demonstrated that transplanted BCR-ABL1 ${ }^{+} \mathrm{Lin}^{-} \mathrm{c}-\mathrm{Kit}^{+} \mathrm{Sca}-{ }^{+}$ (LKS) cells, which harbor the LSC [19] in the retroviral transduction/transplantation model of CML [20], and, particularly, LKS CD150 ${ }^{+} \mathrm{CD}^{-} 8^{-}$(SLAM) cells, were located significantly further away from the endosteum than control cells $(P=0.0029$ and $P=0.0035$, respectively, Figs. 1a, S1A and Supplementary Table 1). Prior in vitro treatment of BCR-ABL1 ${ }^{+}$LKS cells with imatinib led to closer localization of imatinib-treated LKS cells to the endosteum $(P=$ 0.003 , Figs. $1 \mathrm{~b}$ and S1B). However, BCR-ABL1 ${ }^{\mathrm{T} 315 \mathrm{I}+} \mathrm{LIC}$, which are resistant to all TKIs apart from ponatinib and the allosteric inhibitor of the ABL1 kinase, asciminib [21], localized closer to osteoblastic cells than BCR-ABL1 ${ }^{+}$LKS cells $(P<0.0001$, Fig. 1c). We tested whether murine recipients of $\mathrm{BM}$ transduced with $\mathrm{BCR}-\mathrm{ABL1}$, BCR$\mathrm{ABL}^{\mathrm{T} 315 \mathrm{I}}, \mathrm{BCR}-\mathrm{ABL} 1^{\mathrm{M} 351 \mathrm{~T}}, \mathrm{BCR}-\mathrm{ABL} 1^{\mathrm{Y} 253 \mathrm{~F}}$, or BCR$A B L 1^{\mathrm{E} 255 \mathrm{~K}}$ (the latter both P-loop mutations) [20, 22] may recapitulate the accelerated disease course in patients. Indeed, the survival of untreated recipients of BCR$\mathrm{ABL1}^{\mathrm{T} 315 \mathrm{I}}$ - or $\mathrm{BCR}-\mathrm{ABL} 1^{\mathrm{Y} 253 \mathrm{~F}}$ - transduced $\mathrm{BM}$ was significantly shortened compared with recipients of BCR$\mathrm{ABL}^{+}$or BCR-ABL1 ${ }^{\mathrm{M} 351 \mathrm{~T}+} \mathrm{BM}$ (Fig. 1d). Consistent with increased engraftment of $\mathrm{BCR}-\mathrm{ABL} 1^{\mathrm{T} 315 \mathrm{I}+}$ proviral clones and more aggressive disease of BCR-ABL1 $1^{\mathrm{T} 315 \mathrm{I}+}$ CML [20, 23], the disease clonality was significantly higher in recipients of $\mathrm{BCR}-\mathrm{ABL} 1^{\mathrm{T} 315 \mathrm{I}+}$ than $\mathrm{BCR}-\mathrm{ABL} 1^{+} \mathrm{BM}$ $(P=0.035$, Fig. 1e, f). CML was detectable 8 days after transplantation (Fig. S1C-D), and the leukocyte count was higher in recipients of $\mathrm{BCR}-\mathrm{ABL} 1^{\mathrm{T} 315 \mathrm{I}+}$ than $\mathrm{BCR}-\mathrm{ABL} 1^{+}$ BM $(P=0.0335$, Fig. $1 g)$. Similar to human imatinibresistant patients with $\mathrm{BCR}-\mathrm{ABL} 1^{\mathrm{T} 315 \mathrm{I}+}$ disease, blasts were increased in the peripheral blood (Fig. S1E) and the BM of mice with BCR-ABL1 ${ }^{\mathrm{T} 315 \mathrm{I}+} \mathrm{CML}$ (Fig. 1h, i). $\mathrm{GFP}^{+}(\mathrm{BCR}-$ $\mathrm{ABL}^{+}$or $\left.\mathrm{BCR}-\mathrm{ABL} 1^{\mathrm{T} 315 \mathrm{I}+}\right) \mathrm{Gr}^{+} 1^{+}$(Fig. 1j) and in particular $\mathrm{GFP}^{+} \mathrm{CD} 11 \mathrm{~b}^{\text {medium }+}$ (Figs. 1k and S1F) myeloid cells, which likely represent the blasts (Fig. 11), were higher in mice with $\mathrm{BCR}-\mathrm{ABL1} 1^{\mathrm{T} 315 \mathrm{I}+}$ than $\mathrm{BCR}-\mathrm{ABL1}{ }^{+} \mathrm{CML}$. BCR-ABL1 ${ }^{\mathrm{T} 315 \mathrm{I}+} \mathrm{CD} 11 \mathrm{~b}^{\text {medium }+}$ cells expressed the highest levels of c-Kit $(P<0.0001$, Fig. S1G), but lower levels of myeloperoxidase $(P=0.0121$, Fig. S1H-I $)$. 

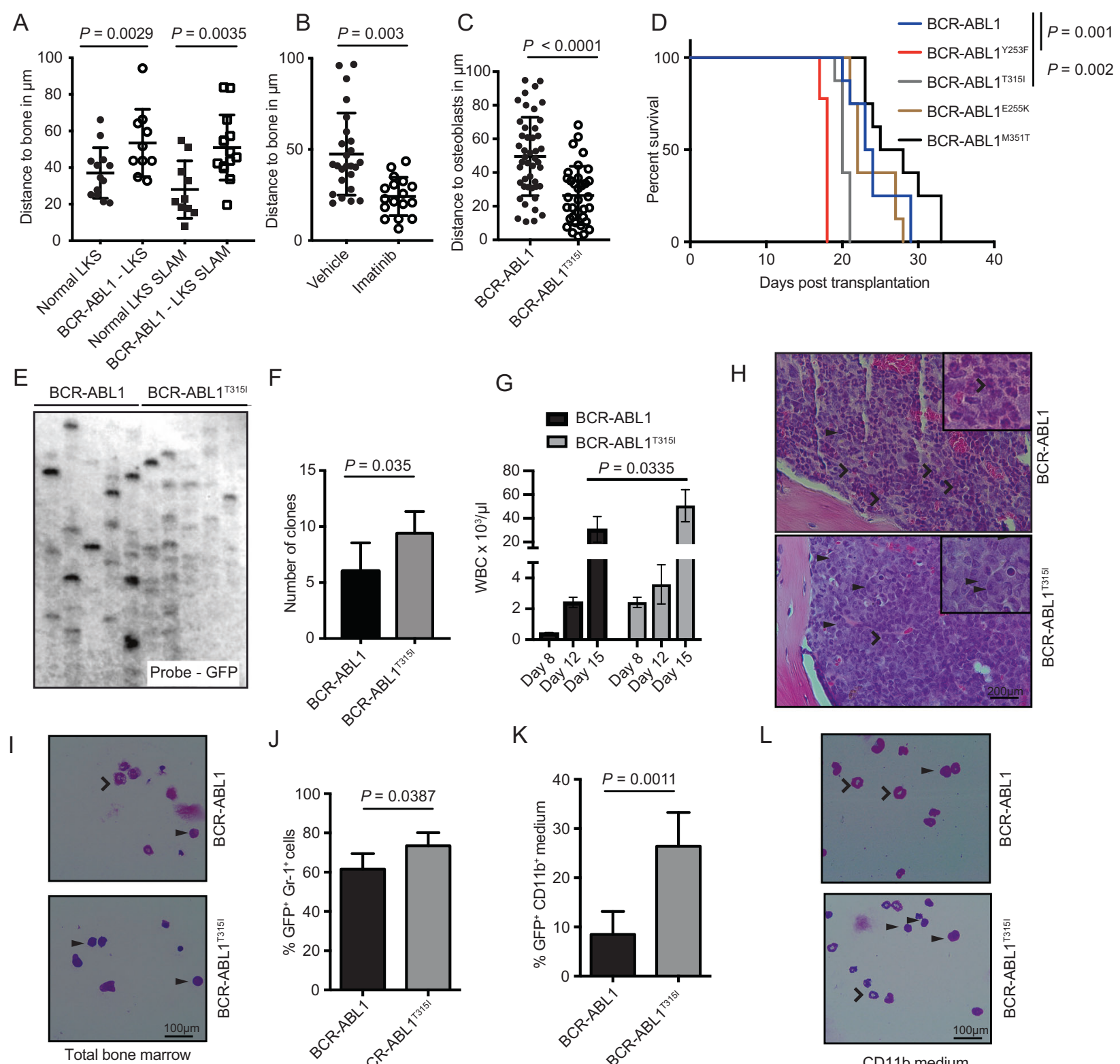

$J$

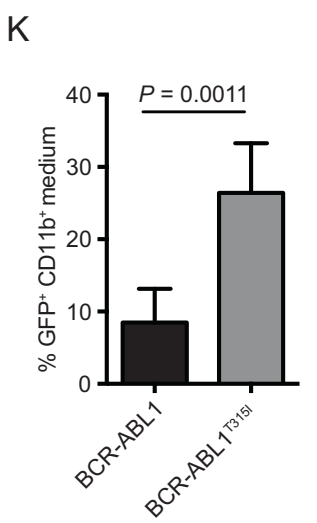

$\mathrm{L}$
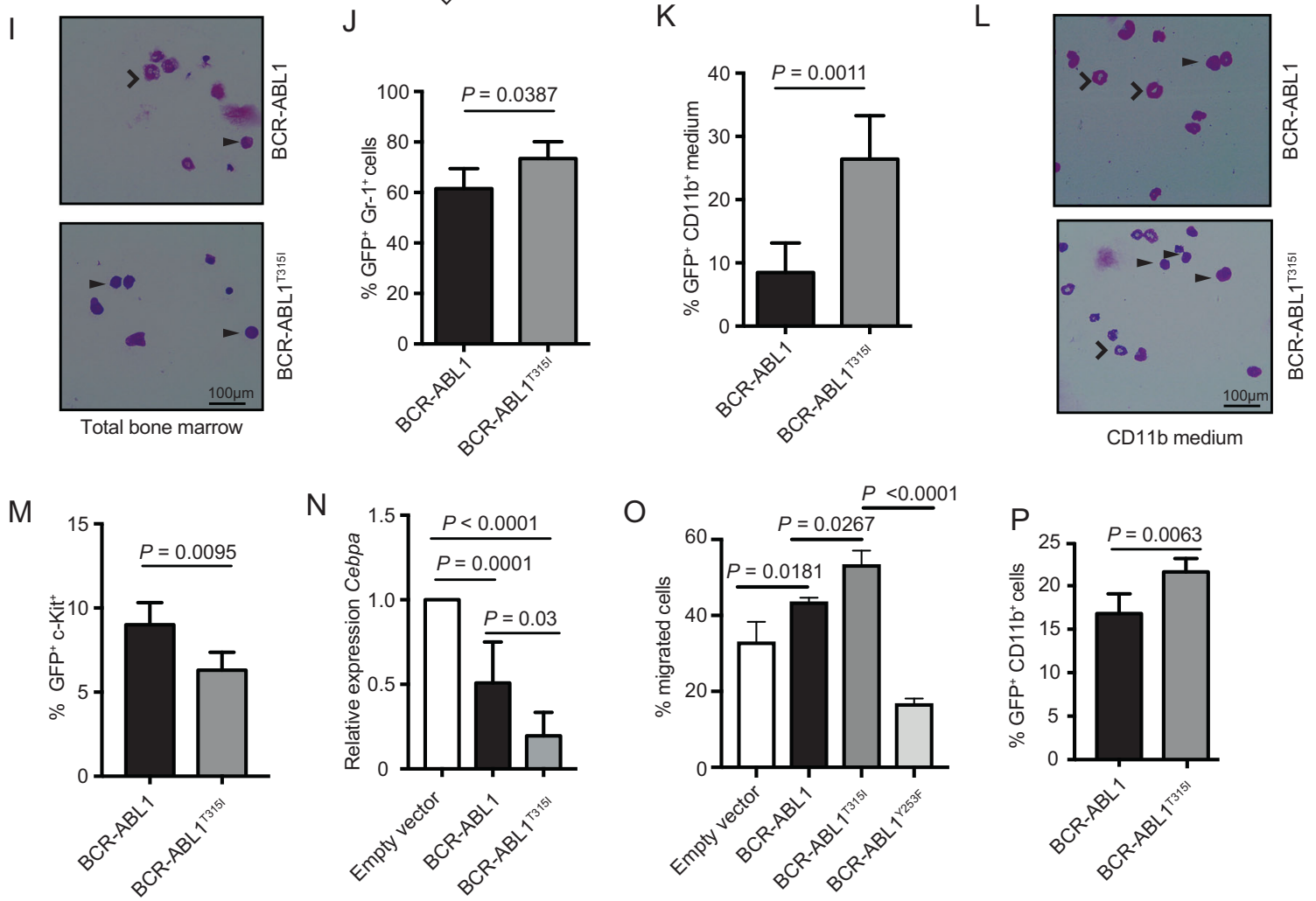

Overall, a decrease of the percentage of $\mathrm{GFP}^{+} \mathrm{c}-\mathrm{Kit}^{+}$ cells $(P=0.0095$, Fig. $1 \mathrm{~m})$ and an increase of $\mathrm{GFP}^{+}$ $(P=0.0019$, Fig. S2B) cells were observed in mice with BCR-ABL1 ${ }^{\mathrm{T} 315 \mathrm{I}+} \mathrm{CML}$. The frequency of BCR$\mathrm{CD}_{4}{ }^{+}(P=0.0003$, Fig. S2A $)$ and $\mathrm{GFP}^{+} \mathrm{CD} 13^{+}$ $\mathrm{ABL}^{\mathrm{T} 315 \mathrm{I}+}\left(\mathrm{GFP}^{+}\right)$LKS cells $(P=0.0045$, Fig. S2C $)$ and 
Fig. 1 BCR-ABL1 ${ }^{\text {T315I }+}$ differ from BCR-ABL1 $^{+}$cells with regards to diverse biological functions. a-c Measurement of the shortest three-dimensional distance of (a) normal (black circles) or BCR-ABL1 ${ }^{+}$LKS (open circles) $\left(P=0.0029, t\right.$-test) or LKS CD150 ${ }^{+}$ CD48 ${ }^{-}$(LKS SLAM) (black (normal) or open (BCR-ABL1 ${ }^{+}$) squares) $(P=0.0035, t$-test $)$ cells or $(\mathbf{b}) \mathrm{BCR}-\mathrm{ABL} 1^{+} \mathrm{LKS}$ in vitro treated with vehicle (black circles) or $10 \mu \mathrm{M}$ imatinib [56] for $4 \mathrm{~h}$ (open circles) $\left(P=0.003, t\right.$-test) to bone and (c) BCR-ABL1 ${ }^{+}$(black circles) versus BCR-ABL1 ${ }^{\mathrm{T} 315 \mathrm{I}+}$ (open circles) LKS cells to osteoblasts $(P<0.0001$, $t$-test) in $\mu \mathrm{m}$. Hematopoietic cells were labeled with the lipophilic dye $\mathrm{DiD}$ and injected into unirradiated Col2.3 kb GFP mice. Imaging was performed $2 \mathrm{~h}$ after injection. The horizontal black line represents the mean. Each symbol represents a distinct cell from three separate experiments. d Kaplan-Meier-style survival curve of untreated BALB/ c recipient mice transplanted with $2.5 \times 10^{5}$ BCR-ABL1-(blue), BCR$\mathrm{ABL}^{\mathrm{Y} 253 \mathrm{~F}}$-(red), BCR-ABL1 ${ }^{\mathrm{T} 315 \mathrm{I}}$-(gray), BCR-ABL1 ${ }^{\mathrm{E} 255 \mathrm{~K}}$-(brown), or BCR-ABL1 ${ }^{\mathrm{M} 351 \mathrm{~T}}$-(black) transduced bone marrow. The difference in survival between BCR-ABL1 ${ }^{+}$and BCR-ABL1 ${ }^{\mathrm{T} 315 \mathrm{I}+}(P=0.002$, Log-rank test) or BCR-ABL1 ${ }^{\mathrm{Y} 253 \mathrm{~F}+}(P=0.001$, Log-rank test) $\mathrm{CML}$ is significant $(n=8-9)$. e, f Southern blot showing distinct proviral integration events (e) and disease clonality (f) in spleens of BALB/c recipients of BCR-ABL1-(lanes 1-5) or BCR-ABL1 ${ }^{\text {T315I }}$-(lanes 6-10) transduced bone marrow at the time of death $(P=0.035, t$-test $)$. g Leukocyte counts $(\mathrm{WBC}) \times 10^{3}$ per $\mu \mathrm{l}$ in the peripheral blood of $\mathrm{BALB} / \mathrm{c}$ recipient mice transplanted with BCR-ABL1-(black) or BCR$\mathrm{ABL1}^{\mathrm{T} 315 \mathrm{I}}$-(gray) transduced bone marrow on days 8,12 , and 15 after transplantation $(P=0.0335$; ANOVA, Tukey test, $n=4-5)$. h Hematoxylin and eosin stain of bone sections of mice with BCR$\mathrm{ABL1}^{+}$(top) or BCR-ABL1 ${ }^{\mathrm{T} 315 \mathrm{I}+}$ (bottom) CML. The open arrows are pointing toward mature myeloid cells, while the closed arrows are pointing toward blasts. The scale bar depicts $200 \mu \mathrm{m}(n=5)$. i Giemsa stain of the cytospins of total bone marrow of representative BALB/c recipient mice transplanted with $\mathrm{BCR}-\mathrm{ABL} 1-$ or $\mathrm{BCR}-\mathrm{ABL1} 1^{\mathrm{T} 315 \mathrm{I}}$ transduced bone marrow on day 15 after transplantation. A total of 50,000 bone marrow cells had been plated. The open arrows are pointing towards mature myeloid cells, while the closed arrows are pointing towards blasts. The scale bar depicts $100 \mu \mathrm{m}(n=5)$. j Percentage of $\mathrm{GFP}^{+}\left(\mathrm{BCR}-\mathrm{ABL1}^{+}\right) \mathrm{Gr}^{+} 1^{+}$myeloid cells in peripheral blood of mice with BCR-ABL1 ${ }^{+}$(black) or BCR-ABL1 ${ }^{\mathrm{T} 315 \mathrm{I}+}$ (gray) CML on day 15 after transplantation $(P=0.0387 ; t$-test, $n=4-6)$. k Percentage of $\mathrm{GFP}^{+}\left(\mathrm{BCR}-\mathrm{ABL1}^{+}\right) \mathrm{CD} 1 \mathrm{~b}^{\text {medium }+}$ myeloid cells in peripheral blood of mice with $\mathrm{BCR}-\mathrm{ABL1}^{+}$(black) or $\mathrm{BCR}-$ $\mathrm{ABL1}^{\mathrm{T} 315 \mathrm{I}+}$ (gray) CML 15 days after transplantation $(P=0.0011$; $t$-test, $n=4-6)$. I Giemsa stain of the cytospins of sorted CD11b medium $^{+}$bone marrow cells from representative BALB/c recipient mice transplanted with BCR-ABL1- or BCR-ABL1 ${ }^{\mathrm{T} 315 \mathrm{I}}$-transduced bone marrow on day 15 after transplantation. A total of 10,000 CD11b medium $^{+}$bone marrow cells had been plated. The open arrows are pointing toward mature myeloid cells, while the closed arrows are pointing towards blasts. The scale bar depicts $100 \mu \mathrm{m}(n=3)$. m Percentage of $\mathrm{GFP}^{+}\left(\mathrm{BCR}^{-\mathrm{ABL}^{+}}{ }^{+}\right)^{\mathrm{c}-\mathrm{Kit}^{+}}$cells in the bone marrow of mice with $\mathrm{BCR}-\mathrm{ABL1}^{+}$(black) or BCR-ABL1 ${ }^{\mathrm{T} 315 \mathrm{I}+}$ (gray) $\mathrm{CML}$ $(P=0.0095$; $t$-test, $n=4-6)$ on day 15 after transplantation. $\mathbf{n}$ Relative expression of Cebpa in total bone marrow of murine recipients of empty vector (white)-, BCR-ABL1 ${ }^{+}$(black)-, or BCR-ABL1 ${ }^{\mathrm{T} 315 \mathrm{I}+}$ (dark gray)-donor bone marrow 15 days after transplantation $(P=$ 0.03; ANOVA, Tukey test, $n=5$ ). o Percentage of empty vector (white)-, BCR-ABL1 ${ }^{+}$(black)-, BCR-ABL1 ${ }^{\mathrm{T} 315 \mathrm{I}+}$ (dark gray)- or BCR-ABL1 ${ }^{\mathrm{Y} 253 \mathrm{~F}+}$ (light gray)-BA/F3 cells which migrated to the bottom chamber containing MS-5 stroma cells in medium containing $10 \%$ serum in a transwell migration assay after $8 \mathrm{~h}(P=0.0267$; ANOVA, Tukey test, $n=3$ ). $10^{5}$ cells had been plated. p Percentage of $\mathrm{BCR}_{-\mathrm{ABL1}^{+}}$(black) or BCR-ABL1 ${ }^{\mathrm{T} 315 \mathrm{I}+}$ (gray) $\left(\mathrm{GFP}^{+}\right)$myeloid $\mathrm{CD}_{11} \mathrm{~b}^{+}$cells adhering to MS-5 stroma cells in vitro $(P=0.0063$; $t$-test, $n=3$ ). $1.5 \times 10^{5}$ cells had been plated and allowed to adhere for $72 \mathrm{~h}$. The data are representative of three independent experiments. myeloid progenitor cells (Fig. S2D) in the BM were reduced. However, the percentage of $\mathrm{BCR}-\mathrm{ABL1}^{\mathrm{T} 315 \mathrm{I}+}$ $\left(\mathrm{GFP}^{+}\right)$LKS SLAM did not differ compared with BCR$\mathrm{ABL}^{+}{ }^{+} \mathrm{CML}$ (Fig. S2E). Concordant with decreased myeloid maturation expression of the myeloid transcription factor Cebpa in total BM cells of mice with BCR$\mathrm{ABL}^{\mathrm{T} 315 \mathrm{I}+} \mathrm{CML}$ was significantly decreased $(P=0.03$, Fig. 1n and Supplementary Table 2). There was a trend toward reduced expression of Spil (PU.1), another myeloid transcription factor, in BCR-ABL1 ${ }^{\mathrm{T} 315 \mathrm{I}+}$ cells (Fig. S2F). The migration of $\mathrm{BCR}-\mathrm{ABL} 1^{\mathrm{T} 315 \mathrm{I}+} \mathrm{BA} / \mathrm{F} 3$ cells $(P=$ 0.0267 , Fig. 10), a frequently used in vitro model $[24,25]$, and the adhesion of BCR-ABL1 ${ }^{\mathrm{T} 315 \mathrm{I}+} \mathrm{CD} 1 \mathrm{~b}^{+}$cells to the stroma cell line MS-5 in vitro $(P=0.0063$, Fig. $1 p)$ were significantly increased compared with BCR-ABL1 ${ }^{+} \mathrm{BA} / \mathrm{F} 3$ cells. In summary, these findings suggest that BCR-ABL1 ${ }^{+}$ and BCR-ABL1 ${ }^{\mathrm{T} 315 \mathrm{I}+}$ leukemia cells differ with respect to homing localization in the BMM, migration, adhesion, disease aggressiveness and (immuno-) phenotype.

\section{The actin cytoskeleton and expression and function of focal adhesion kinase differ between BCR- $\mathrm{ABL1}^{\mathrm{T3151+}}$ and BCR-ABL1 ${ }^{+}$cells}

We hypothesized that differences in the actin cytoskeleton and/or focal adhesion kinase (FAK) [26], which is phosphorylated by BCR-ABL1 [27], underlie the increased migration (Fig. 1o) and adhesion (Fig. 1p) of BCR$\mathrm{ABL1}^{\mathrm{T} 315 \mathrm{I}+}$ cells. Indeed, immunofluorescence staining of 3 T3 fibroblasts, frequently used as model system to visualize the actin cytoskeleton in BCR-ABL1 ${ }^{+}$cells $[28,29]$, revealed that the evenly distributed and polymerized actin cytoskeleton in empty vector-transduced 3T3 cells was less finely arranged in BCR-ABL1 ${ }^{+}$and decreased in BCR$\mathrm{ABL1}^{\mathrm{T} 315+}$ 3T3 cells (Figs. 2a and S3A). Staining of FAK, a focal adhesion protein involved in actin polymerization [30] and cytoskeletal stability [31], which lies downstream of the integrin receptors, in 3T3 cells transduced with empty vector-expressing retrovirus, was punctate, possibly consistent with an intact focal adhesosome. However, the punctae were reduced in BCR-ABL1 ${ }^{+}$and completely dispersed and granular in BCR-ABL1 $1^{\mathrm{T} 315 \mathrm{I}+} 3 \mathrm{~T} 3$ cells $(P<$ 0.0001 ; Fig. $2 b, c)$. Phosphorylation at phosphotyrosine pY397 in FAK, an autophosphorylation site [32], was higher in $\mathrm{BCR}-\mathrm{ABL1}^{+}$compared with $\mathrm{BCR}-\mathrm{ABL1} 1^{\mathrm{T} 315 \mathrm{I}+}$ BA/F3 (Figs. 2d, e and S3B) and $\mathrm{Lin}^{-}$cells (Fig. S3C), while phosphorylation at pY925 was similar. shRNAmediated knockdown of Ptk2 (FAK) (Fig. S3D) or the gene of another adapter protein at focal adhesion sites, paxillin

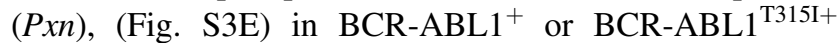
donor BM did not lead to survival prolongation in recipient wildtype mice. Taken together, these data suggest that the cytoskeleton differs between $\mathrm{BCR}-\mathrm{ABL} 1^{+}$versus 
A
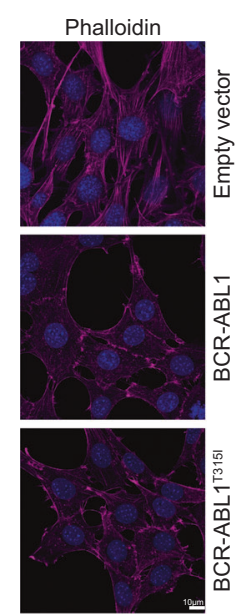

E
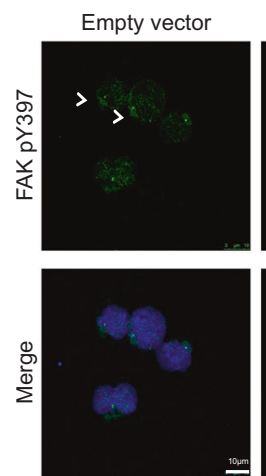

B

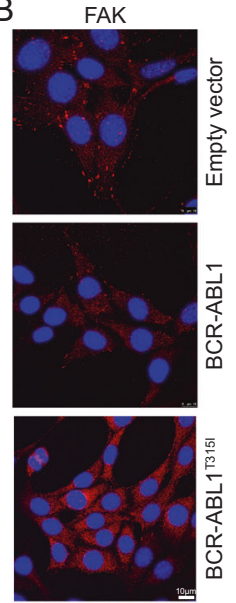

C

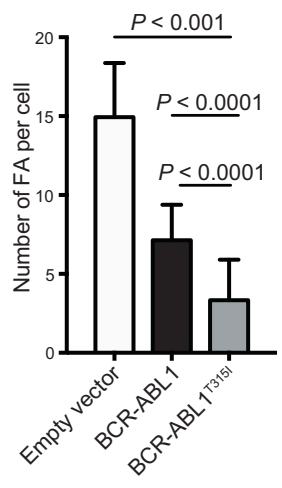

D

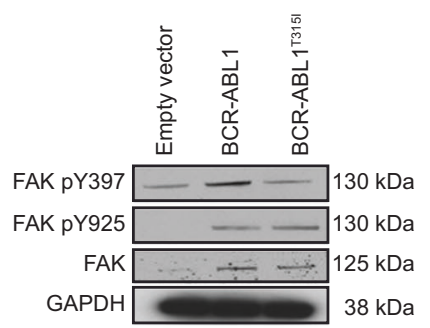

Fig. 2 The actin cytoskeleton and expression of focal adhesion kinase differ between $\mathrm{BCR}-\mathrm{ABL1}{ }^{\mathrm{T} 315 \mathrm{I}+}$ and $\mathrm{BCR}-\mathrm{ABL1}^{+}$cells. Immunofluorescence studies on $3 \mathrm{~T} 3$ fibroblasts transduced with empty vector, BCR-ABL1 or BCR-ABL1 ${ }^{\mathrm{T} 315 \mathrm{I}}$ grown on coverslips and stained with phalloidin (a) or an antibody to FAK (b). c Quantification of the focal adhesions (FA) per 3T3 fibroblast transduced with empty vector (white), BCR-ABL1 (black), or BCR-ABL1 ${ }^{\text {T315I }}$ (gray) from (b) $(P<0.0001$; ANOVA, Tukey test, $n=3)$. The data in $(\mathbf{a}-\mathbf{c})$ are from three independent experiments. d Immunoblot showing the expression

BCR-ABL1 ${ }^{\text {T315I+ }}$ cells. Possibly due to differing phosphorylation of FAK by BCR-ABL1 versus BCR-ABL1 ${ }^{\mathrm{T} 315 \mathrm{I}}$ focal adhesions may be dysfunctional in BCR-ABL1 ${ }^{\mathrm{T} 315 \mathrm{I}+}$ cells.

\section{Integrin $\beta 3$ expression on $\mathrm{BCR}-\mathrm{ABL1} 1^{\mathrm{T} 3151+}$ cells influences $\mathrm{CML}$ progression}

Given our above observations, the known involvement of pY397 of FAK for FAK-mediated cell migration and the phosphorylation of FAK at pY397 upon clustering of integrins [32], we assessed expression of various integrins. While there was no difference in mean fluorescence intensity of integrin $\alpha 5$ (CD49e) (Fig. S4A), integrin $\alpha \mathrm{IIb}$ (CD41), which forms a heterodimer with integrin $\beta 3$ [33], was less expressed on BCR-ABL1 ${ }^{\mathrm{T} 315 \mathrm{I}+}$ compared with BCR-ABL1 ${ }^{+}$cells $(P=0.0103$, Fig. S4B). Further, integrin of FAKpY397 (130 kDa), FAKpY925 (130 kDa), FAK (125 kDa), or glyceraldehyde 3-phosphate dehydrogenase (GAPDH) (38 kDa) in lysates of BA/F3 cells transduced with empty vector, BCR-ABL1 or BCR-ABL1 ${ }^{\mathrm{T} 315 \mathrm{I}}$. The immunoblot is representative of three experiments. e Immunofluorescence studies of BA/F3 cells transduced with empty vector-, BCR-ABL1-, BCR-ABL1 ${ }^{\mathrm{T} 315 \mathrm{I}}$-, or BCR-ABL1 ${ }^{\mathrm{Y} 253 \mathrm{~F}}$ expressing retrovirus' stained with an antibody to FAKpY397 and 4',6diamidino-2-phenylindole (DAPI). The data are representative of two experiments.

$\beta 3$, previously implicated in the development and progression of AML [34], was more highly expressed on BCR$\mathrm{ABL1}^{\mathrm{T} 315 \mathrm{I}+}$ versus $\mathrm{BCR}-\mathrm{ABL1}^{+}$or empty vectortransduced BA/F3 cells by immunoblotting (Figs. 3a and S4C) and super-resolution microscopy [35] $(P=0.0228$, Figs. $3 \mathrm{~b}$ and S4D). Primary Gr- $1^{+} \mathrm{BCR}-\mathrm{ABL} 1^{\mathrm{T} 315 \mathrm{I}+}$ myeloid cells $(P=0.0306$, Fig. $3 \mathrm{c})$ and total $\mathrm{GFP}^{+} \mathrm{BM}$ cells $(P=0.0021$, Fig. 3d) from CML mice also revealed significantly increased expression of integrin $\beta 3$. This was also independently confirmed using stable isotope labeling with amino acids in cell culture-based quantitative mass spectrometry (Fig. S4E, Supplementary Table 3). Consistently, coimmunoprecipitation of $\mathrm{BA} / \mathrm{F} 3$ cells transduced with BCR-ABL1 or BCR-ABL1 ${ }^{\mathrm{T} 315 \mathrm{I}}$ with an antibody to integrin $\beta 3$ revealed increased binding of $F A K$ to integrin $\beta 3$ in BCR-ABL1 ${ }^{\mathrm{T} 315 \mathrm{I}+}$ cells (Fig. S4F). Exogenous overexpression of integrin $\beta 3$ on $\mathrm{BCR}-\mathrm{ABL}^{+}$or 
A

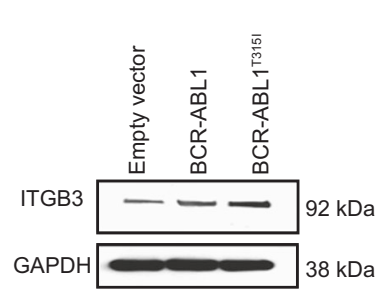

B

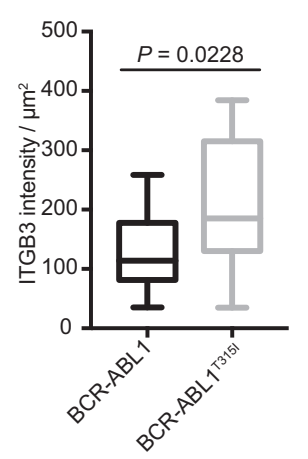

C

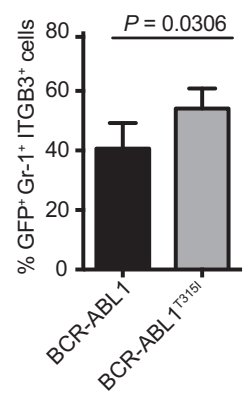

D

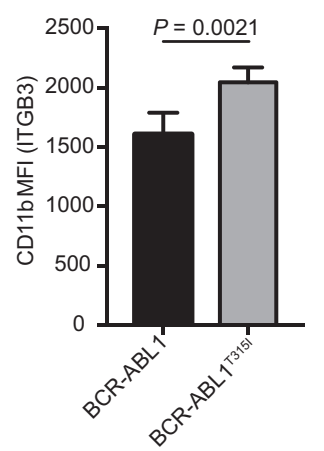

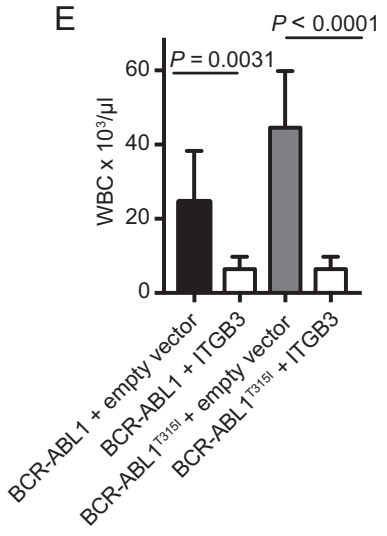

$\mathrm{F}$

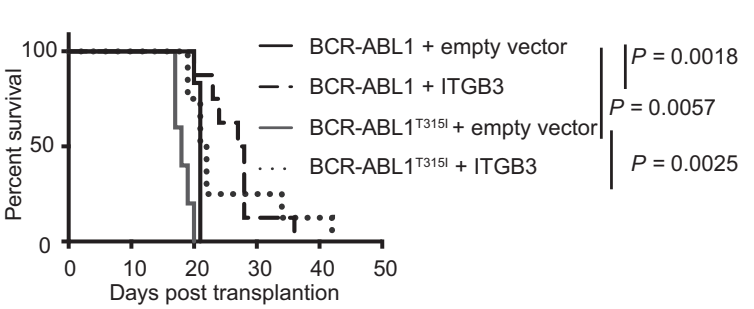

G

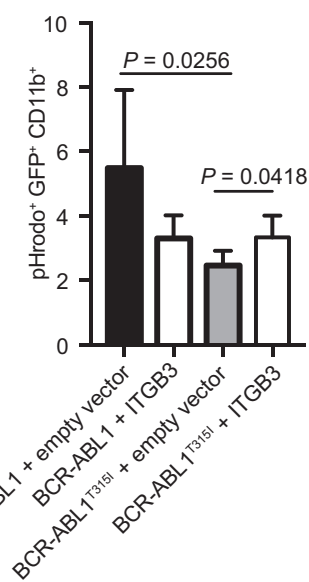

Fig. 3 Integrin $\beta 3$ is involved in progression of $B C R-A B L 1^{\mathrm{T} 315 I+}$ CML. a Immunoblot showing the expression of integrin $\beta 3$ (ITGB3) $(92 \mathrm{kDa})$ or GAPDH $(38 \mathrm{kDa})$ in lysates of BA/F3 cells transduced with empty vector, BCR-ABL1 or BCR-ABL1 $1^{\mathrm{T} 315 \mathrm{I}}$. The immunoblot is representative of three experiments. $\mathbf{b}$ Results of super-resolution microscopy (dSTORM) for immunolabeled integrin $\beta 3$ showing enhanced expression of the epitope on the surface of $\mathrm{BA} / \mathrm{F} 3$ cells transduced with BCR-ABL1 ${ }^{\text {T315I }}$ versus BCR-ABL1 $(P=0.0228$; $t$-test, $n=3)$. The data are representative of three experiments. c Percentage of $\mathrm{GFP}^{+}\left(\mathrm{BCR}-\mathrm{ABL} 1^{+}\right) \mathrm{Gr}^{-} 1^{+}$integrin $\beta 3^{+}$myeloid cells in peripheral blood of mice with $\mathrm{BCR}-\mathrm{ABL1}^{+}$(black) or BCR$\mathrm{ABL1}^{\mathrm{T} 315 \mathrm{I}+}$ (gray) CML on day 15 after transplantation $(P=0.0306$; $t$-test, $n=4-6$ ). d Mean fluorescence intensity (MFI) of integrin $\beta 3$ on

BCR-ABL1 ${ }^{\mathrm{T} 315 \mathrm{I}+}$ donor $\mathrm{BM}$ by retroviral cotransduction [20] (Fig. S3G), led to significantly reduced leukocyte counts in peripheral blood $\left(P=0.0031\right.$ for BCR-ABL1 ${ }^{+}$ and $P<0.0001$ for BCR-ABL1 ${ }^{\mathrm{T} 315 \mathrm{I}+}$, Fig. 3e) and prolonged survival $\left(P=0.0018\right.$ for BCR-ABL1 ${ }^{+}$and $P=$ 0.0025 for BCR-ABL1 ${ }^{\text {T315I+ }}$, Fig. 3f) in most recipients of integrin $\mathrm{B3}^{+}$compared with empty vector-transduced BCR$\mathrm{ABL}^{+}{ }^{+}$or BCR-ABL1 ${ }^{\mathrm{T} 315 \mathrm{I}+}$ donor BM. Homing of empty vector- or integrin $\beta 3$-overexpressing LIC did not differ (Fig. S4H-I). In contrast, knockdown of integrin $\beta 3$ on BCR-ABL1 $^{+}$or BCR-ABL1 ${ }^{\mathrm{T} 315 \mathrm{I}+}$ donor $\mathrm{BM}$ did not alter survival (Fig. S4J-K). Testing phagocytic activity, characteristic of mature myeloid cells, we demonstrated that phagocytosis was significantly reduced in BCR-ABL1 $^{\text {T315I+ }}$ versus BCR-ABL1 $^{+}$myeloid cells
$\mathrm{CD}_{11 \mathrm{~b}^{+}}$cells from bone marrow of mice with BCR-ABL1 ${ }^{+}$(black) or BCR-ABL1 ${ }^{\mathrm{T} 315 \mathrm{I}+}$ (gray) CML on day 15 after transplantation $(n=5)$. e, f Leukocyte counts $(\mathrm{WBC}) \times 10^{3}$ per $\mu \mathrm{l}$ in peripheral blood $(P<$ 0.0001 for BCR-ABL1 ${ }^{\mathrm{T} 315 \mathrm{I}+}$; $t$-test, $\left.n=7-8\right)$ (e) and Kaplan-Meierstyle survival curve (f) of BALB/c recipient mice transplanted with bone marrow cotransduced with BCR-ABL1- or BCR-ABL1 ${ }^{\mathrm{T} 315 \mathrm{I}}$ expressing retrovirus and integrin $\beta 3$ (ITGB3)-overexpressing retrovirus $\left(P=0.0025\right.$ for BCR-ABL1 ${ }^{\mathrm{T} 315 \mathrm{I}}, \mathrm{Log}$-rank test). $\mathbf{g}$ Percentage of $\mathrm{BCR}^{-\mathrm{ABL}^{+}}{ }^{+}$or $\mathrm{BCR}-\mathrm{ABL} 1^{\mathrm{T} 315 \mathrm{I}+} \mathrm{CD} 11 \mathrm{~b}^{+}$myeloid cells cotransduced with empty vector or integrin $\beta 3\left(\mathrm{GFP}^{+}\right)$from mice with established disease after incubation for $90 \mathrm{~min}$ with pHrodophycoerythrin (PE)-labeled Escherichia coli particles $(P=0.0256$; $t$-test, $n=5$ ).

$(P=0.0256$, Fig. $3 \mathrm{~g})$. However, overexpression of integrin $\beta 3$ on BCR-ABL1 ${ }^{\mathrm{T} 315 \mathrm{I}+}$ myeloid cells 'rescued' or restored the phagocytosis of bacterial particles $(P=0.0418$, Fig. $3 \mathrm{~g})$. In summary, these data suggested that integrin $\beta 3$ plays a role in the outcome of, particularly, BCR-ABL1 $1^{\mathrm{T} 315 \mathrm{I}+}$ CML, while also influencing the differentiation of BCR$\mathrm{ABL}^{+}{ }^{+}$and BCR-ABL1 ${ }^{\mathrm{T} 315 \mathrm{I}+}$ myeloid cells.

\section{Fibronectin is decreased in the BMM of mice with BCR-ABL1 $^{\text {T3151+ }}$ CML}

Next, we tested the adhesion of empty vector-, BCR-ABL1or BCR-ABL1 ${ }^{\mathrm{T} 315 \mathrm{I}+}$ primary $\mathrm{BM}$ cells to the $\mathrm{ECM}$ protein fibronectin, one of the ligands of integrin $\beta 3$. This revealed increased adhesion of BCR-ABL1 ${ }^{\mathrm{T} 315 \mathrm{I}+}$ cells to fibronectin 
compared with empty vector- or BCR-ABL1-transduced cells $(P<0.0001$, Fig. 4a). We hypothesized that BCR$\mathrm{ABL1}^{\mathrm{T} 315 \mathrm{I}+}$ CML cells, similar to other cancers [29], may deposit less fibronectin. Indeed, 3T3 fibroblasts transduced with BCR-ABL1 ${ }^{\text {T315I }}$ deposited significantly less fibronectin than BCR-ABL1 ${ }^{+}$fibroblasts (Fig. S5A). Deposition of fibronectin was kinase-dependent, as treatment of BCR$\mathrm{ABL}^{+}, \mathrm{BCR}^{-\mathrm{ABL}} 1^{\mathrm{Y} 253 \mathrm{~F}+}$, or $\mathrm{BCR}^{-\mathrm{ABL}} 1^{\mathrm{T} 315 \mathrm{I}+} 3 \mathrm{~T} 3$ fibroblasts with the TKI ponatinib significantly increased fibronectin deposition, while imatinib had no effect on imatinib-resistant BCR-ABL1 mutants (Fig. 4b). Less fibronectin was also found in the BMM of mice with CML due to BCR-ABL1 ${ }^{\mathrm{T} 315 \mathrm{I}}$, BCR-ABL1 ${ }^{\mathrm{E} 255 \mathrm{~K}}$, or $\mathrm{BCR}$ $\mathrm{ABL} 1^{\mathrm{Y} 253 \mathrm{~F}}$, but not BCR-ABL1 ${ }^{\mathrm{M} 351 \mathrm{~T}}$ compared with control mice (Figs. $4 \mathrm{c}$ and S5B). In order to test whether the generation of fibronectin by leukemia cells influences leukemia progression and accelerates $\mathrm{BCR}^{-\mathrm{ABL}^{+}}{ }^{+} \mathrm{CML}$ similar to BCR-ABL1 ${ }^{\mathrm{T} 315 \mathrm{I}+} \mathrm{CML}$, we transduced the $\mathrm{BM}$ of fibronectin flox/flox $\times$ Mx1-Cre (FN Mx1-Cre) mice with BCR-ABL1 or BCR-ABL1 ${ }^{\mathrm{T} 315 \mathrm{I}}$, before transplantation into wildtype recipients and subsequent administration of poly I: $\mathrm{C}$ to induce Cre (Fig. S5C). This led to a significant increase of the number of leukocytes in the peripheral blood of mice that had received BCR-ABL1 ${ }^{+} \mathrm{FN}$ Mx1-Cre BM $(P=0.0403$, Fig. $4 \mathrm{~d})$ and significant shortening of survival of those mice which received BCR-ABL1 ${ }^{+}(P=0.0162$, Fig. 4e) or BCR-ABL1 ${ }^{\mathrm{T} 315 \mathrm{I}+}$ FN Mx1-Cre BM compared with their respective controls $(P=0.0018$, Fig. S5D). All mice succumbed to CML-like disease. Later deletion of fibronectin in LIC had the same effect (Fig. 4f, g). In contrast, no effect on survival was observed when BCR-ABL1 ${ }^{+}$ or $\mathrm{BCR}-\mathrm{ABL} 1^{\mathrm{T} 315 \mathrm{I}}$ wildtype $\mathrm{BM}$ was transplanted into fibronectin flox/flox $\times$ Col1a2-Cre (FN Col1a2-Cre) mice (Fig. S5E-F), characterized by lack of production of fibronectin by fibroblasts [36]. In summary, these data suggest that BCR-ABL1 ${ }^{\mathrm{T} 315 \mathrm{I}+} \mathrm{CML}$ cells produce less fibronectin than $\mathrm{BCR}-\mathrm{ABL1}^{+}$cells and that fibronectin production by leukemia cells influences CML progression.

\section{Integrin-linked kinase is involved in fibronectin deposition and influences survival in BCR-ABL1 ${ }^{\text {T315I+ }}$ CML}

Hypothesizing that BCR-ABL1 ${ }^{\mathrm{T} 315 \mathrm{I}+}$ leukemia cells deposit less fibronectin than BCR-ABL1 ${ }^{+}$leukemia cells due to differences in signaling pathways, we focused on ILK, a pseudokinase belonging to the family of RAF-like kinases involved in integrin-mediated signal transduction [37] and fibronectin deposition [38, 39]. ILK is linked to the cytoplasmic domains of integrins $\beta 1$ and $\beta 3$ [40]. We demonstrated that levels of total ILK and ILK phosphorylated at its autophosphorylation site S246 (ILK pS246) were increased in $\mathrm{BCR}-\mathrm{ABL} 1^{\mathrm{T} 315 \mathrm{I}+}$ compared with $\mathrm{BCR}-\mathrm{ABL1}{ }^{+} \mathrm{BA} / \mathrm{F} 3$ (Figs. 5a and S6A-B) or Lin $^{-}$cells (Fig. S6C-D). Treatment with ponatinib reduced levels of ILK, and ILK pS246 in $\mathrm{BCR}_{-} \mathrm{ABL1}^{+}$and $\mathrm{BCR}-\mathrm{ABL1} 1^{\mathrm{T} 315 \mathrm{I}+} \mathrm{BA} / \mathrm{F} 3$ cells, suggesting that protein levels of ILK and possibly phosphorylation of ILK may be BCR-ABL1-dependent (Figs. 5b and S6E-F), though not directly mediated by the tyrosine kinase BCR-ABL1. ILK and integrin $\beta 3$ colocalized in BCR$\mathrm{ABL}^{+}{ }^{+}$and $\mathrm{BCR}-\mathrm{ABL} 1^{\mathrm{T} 315 \mathrm{I}+} \mathrm{BA} / \mathrm{F} 3$ cells, but the staining pattern for ILK and integrin $\beta 3$ was more diffuse and less punctate in BCR-ABL1 ${ }^{\mathrm{T} 315 \mathrm{I}+}$ compared with BCR-ABL1 ${ }^{+}$ cells (Figs. 5c and S6G). Consistently, in spite of the overexpression of integrin $\beta 3$, binding between ILK and integrin $\beta 3$ was reduced in $\mathrm{BCR}-\mathrm{ABL} 1^{\mathrm{T} 315 \mathrm{I}+}$ compared with BCR-ABL1 ${ }^{+}$cells (Figs. $5 \mathrm{~d}$ and S6H). Cotransduction of donor BM with BCR-ABL1- versus BCR-ABL1 ${ }^{\mathrm{T} 315 \mathrm{I}}$ expressing retrovirus and scrambled- or Ilk shRNAexpressing lentivirus $(P=0.0133$, Fig. S6I) led to a significant reduction of leukocyte counts $(P=0.0018$, Fig. 5e) and significant prolongation of survival $(P=0.0476$, Figs. $5 \mathrm{f}$ and S6I) in recipients of BCR-ABL1 ${ }^{\mathrm{T} 315 \mathrm{I}+}$ sh $I l k^{+}$ donor BM compared with controls, also when knockdown of $I l k$ was induced at a later timepoint after transplantation $(P=0.0028$, Figs. $5 \mathrm{~g}$ and S6J). Knockdown of $I l k$ also led to an increase in fibronectin deposition by BCR-ABL1 ${ }^{\mathrm{T} 315 \mathrm{I}+}$ sh $\mathrm{Ilk}^{+} 3 \mathrm{~T} 3$ fibroblasts (Fig. 5h) and in the BMM of recipients of BCR-ABL1 ${ }^{\mathrm{T} 315 \mathrm{I}+}$ sh $I l k^{+}$donor BM compared with controls (Figs. 5i and S6K). As BCR-ABL1 only phosphorylates tyrosine and not serine residues, we tested the phosphorylation of ILK at pS246 after treatment of BCR-ABL1 ${ }^{\mathrm{T} 315 \mathrm{I}+} \mathrm{BA} / \mathrm{F} 3$ cells with vehicle, the ILK inhibitor Cpd22, ponatinib or the phosphoinositide-3-kinase (PI3K) inhibitor wortmannin, as PI3K is activated by BCRABL1 [41]. This revealed that levels of pS246ILK were decreased by $\mathrm{Cpd} 22$, ponatinib, and wortmannin, while total ILK was mostly decreased by ponatinib (Figs. $5 \mathrm{j}$ and S6L-M), suggesting that PI3K may differentially phos-

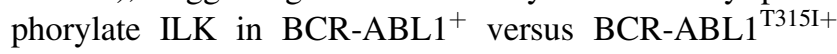
cells. Taken together, these data suggest that binding between ILK and integrin $\beta 3$ is impaired in BCR$\mathrm{ABL}^{\mathrm{T} 315 \mathrm{I}+}$ cells and that ILK plays an important role in progression of $\mathrm{BCR}-\mathrm{ABL1} 1^{\mathrm{T} 315 \mathrm{I}+} \mathrm{CML}$, at least partly via modulation of fibronectin levels in the BMM.

\section{Treatment with fibronectin prolongs survival in BCR-ABL1 $^{\text {T315I+ }}$ CML}

Hypothesizing that replenishing reduced fibronectin levels in mice with $\mathrm{BCR}-\mathrm{ABL} 1^{\mathrm{T} 315 \mathrm{I}+} \mathrm{CML}$ may decelerate leukemia progression, we transplanted LIC, resuspended in vehicle or fibronectin, intrafemorally into mice as proof of principle. This plus two further intrafemoral applications of fibronectin led to a significant reduction of leukocytes in 
A

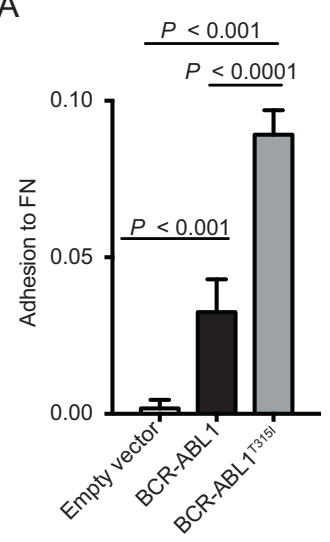

D

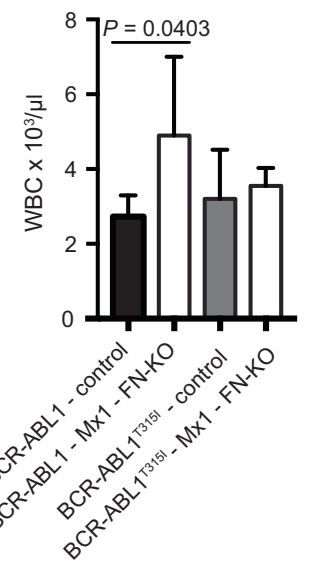

$\mathrm{F}$

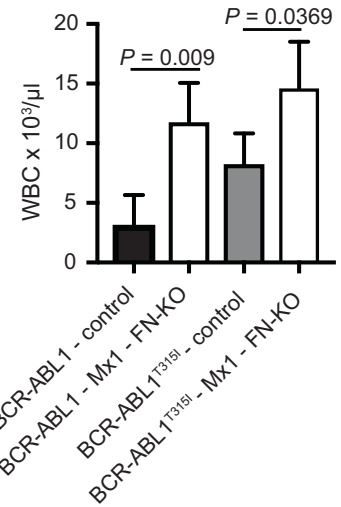

Fig. 4 Fibronectin is decreased in the BMM of mice with BCRABL1 $^{\text {T315I+ }}$ CML. a Optical density read at $570 \mathrm{~nm}$ after adhesion of sorted empty vector ${ }^{+}, \mathrm{BCR}_{-\mathrm{ABL1}}{ }^{+}$, or $\mathrm{BCR}-\mathrm{ABL1} 1^{\mathrm{T} 315 \mathrm{I}+}\left(\mathrm{GFP}^{+}\right)$ $\mathrm{CD} 11 \mathrm{~b}^{+}$splenocytes to fibronectin $(\mathrm{FN})$ in vitro $(P<0.0001$ for $\mathrm{BCR}-$ ABL1 versus BCR-ABL1 ${ }^{\text {T315I}}$; ANOVA, Tukey test, $n=3$ ). $10^{5}$ cells had been plated and allowed to adhere for $72 \mathrm{~h}$. The data are representative of three independent experiments. b Immunofluorescence of $3 \mathrm{~T} 3$ fibroblasts transduced with BCR-ABL1-, BCR-ABL1 ${ }^{\mathrm{T} 315 \mathrm{I}}$-, or $\mathrm{BCR}-\mathrm{ABL} 1^{\mathrm{Y} 253 \mathrm{~F}}$-expressing retrovirus, treated with vehicle, $750 \mathrm{nM}$ imatinib or $60 \mathrm{nM}$ ponatinib for $6 \mathrm{~h}$, stained with an antibody to fibronectin (pink). The nuclei are counterstained with DAPI. c Immunohistochemistry for fibronectin (detected by immunoperoxidase using yellow-brown horseradish-peroxidase chromogen) on bones of $\mathrm{BALB} / \mathrm{c}$ recipient mice transplanted with empty vector-, BCR-ABL1-, or $\mathrm{BCR}-\mathrm{ABL1} 1^{\mathrm{T} 315 \mathrm{I}}$-transduced bone marrow at time of death. The scale bar depicts $200 \mu \mathrm{m}(n=3)$. Leukocyte counts $(\mathrm{WBC}) \times 10^{3}$ per $\mu \mathrm{l}$ in peripheral blood $(P=0.0403$ for BCR-ABL1; $t$-test, $n=5-6)$ on day 12 after transplantation (d) and Kaplan-Meier-style survival curve (e) of C57BL/6 recipient mice transplanted with $\mathrm{FN} \mathrm{fl/fl} \mathrm{Mx1-Cre}{ }^{-}$or $\mathrm{FN} \mathrm{fl/fl}$ $\mathrm{Mx} 1-\mathrm{Cre}^{+}$bone marrow transduced with BCR-ABL1 $(P=0.0162$, Logrank test) (e) or BCR-ABL1 ${ }^{\mathrm{T} 315 \mathrm{I}}$ (d). $10 \mathrm{mg} / \mathrm{kg}$ polyinosinic:polycytidylic acid (poly I:C) per dose was administered on days 1, 2, 3, and 5 after transplantation. f, g Leukocyte counts $(\mathrm{WBC}) \times 10^{3}$ per $\mu \mathrm{l}$ in peripheral blood on day 12 after transplantation $(P=0.009$ for BCR$\mathrm{ABL}^{+}$; $t$-test, $n=5-6$ ) (f) and Kaplan-Meier-style survival curve (g) of C57BL/6 recipient mice transplanted with $\mathrm{FN}$ fl/fl $\mathrm{Mx} 1-\mathrm{Cre}^{-}$or $\mathrm{FN} \mathrm{fl} / \mathrm{fl}$ $\mathrm{Mx} 1-\mathrm{Cre}^{+}$bone marrow transduced with BCR-ABL1 $(P=0.0003$, Logrank test) or BCR-ABL1 ${ }^{\mathrm{T} 315 \mathrm{I}}(\mathrm{g})$. Ten milligram per kilogram polyinosinic:polycytidylic acid (poly I:C) per dose was administered on days 8,9 , and 10 after transplantation. 

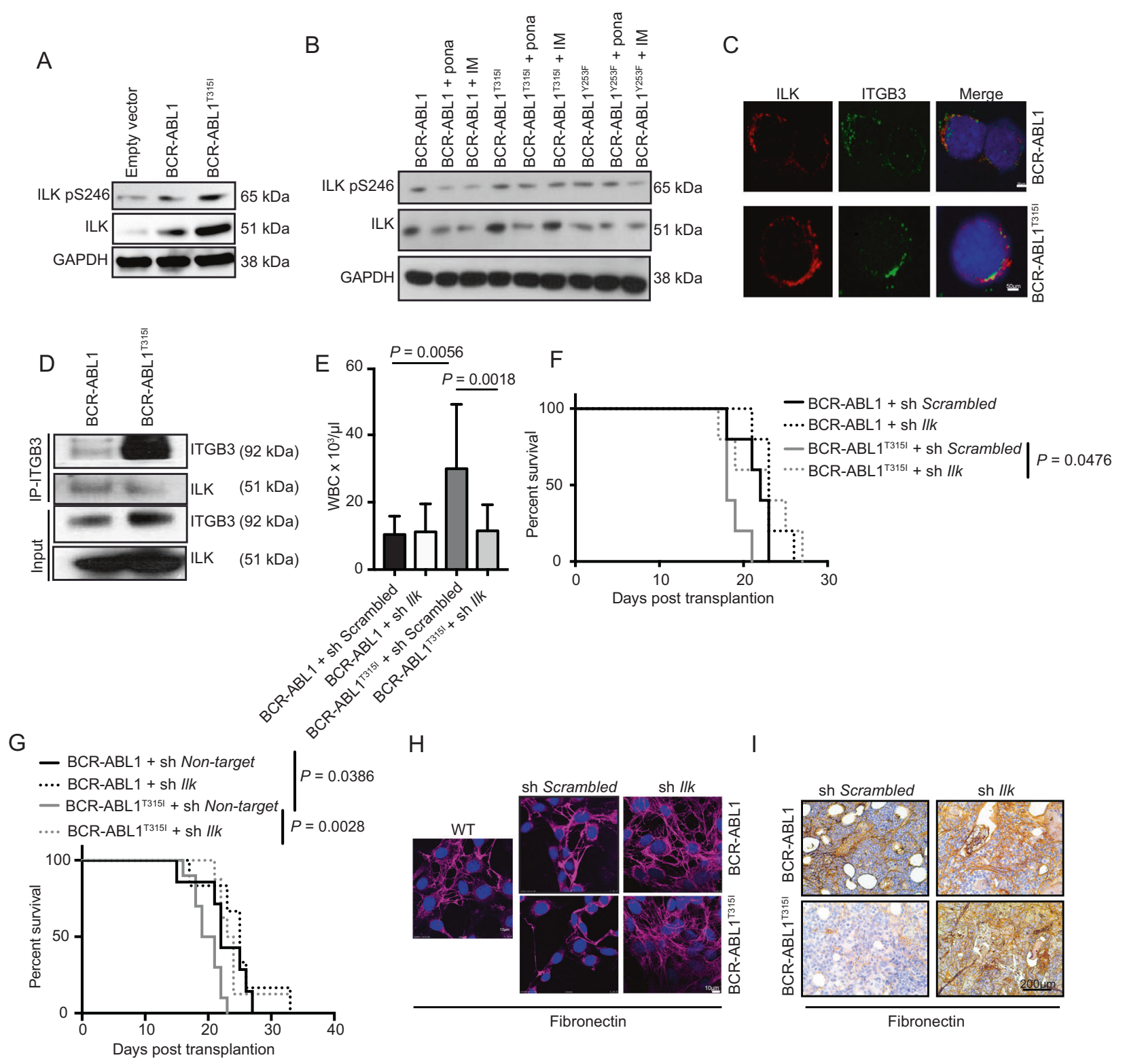

$\mathrm{H}$
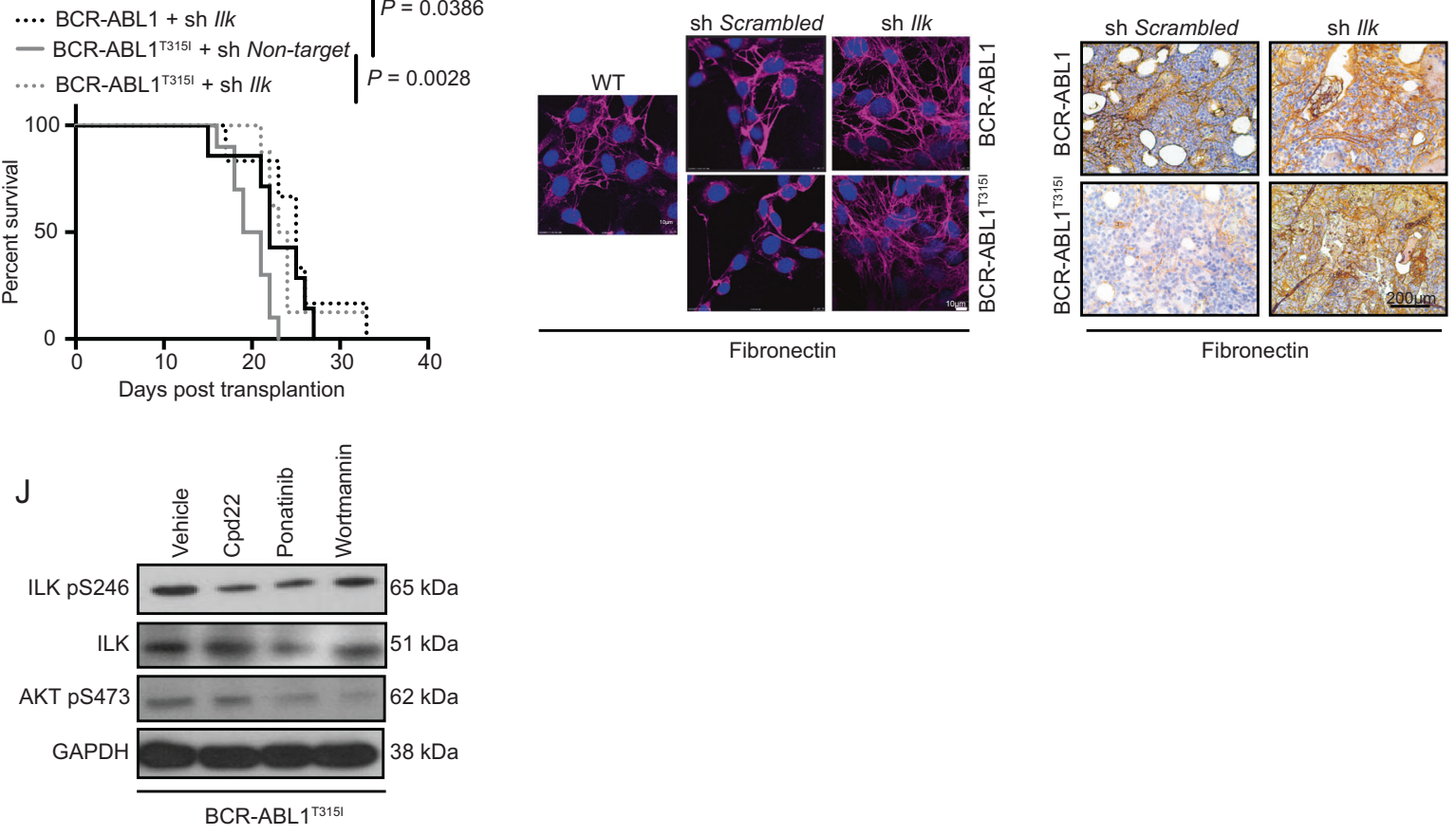

peripheral blood ( $P=0.0096$; Fig. 6a) and significant survival prolongation $(P=0.0246$; Fig. $6 \mathrm{~b})$ in mice with BCR$\mathrm{ABL1} 1^{\mathrm{T} 315 \mathrm{I}+} \mathrm{CML}$ compared with controls. Intravenous administration of fibronectin also significantly prolonged

the survival of mice with $\mathrm{BCR}-\mathrm{ABL1} 1^{\mathrm{T} 315 \mathrm{I}+} \mathrm{CML}(P=$ 0.017; Fig. 6c) and increased fibronectin levels in the BM (Fig. S7A). However, administration of fibronectin to mice with BCR-ABL1 ${ }^{+}$B-cell acute lymphoblastic leukemia 
Fig. 5 Integrin-linked kinase influences fibronectin deposition and survival in BCR-ABL1 ${ }^{\text {T315I+ }}$ CML. a Immunoblot showing the expression of ILK pS246 $(65 \mathrm{kDa})$, ILK $(51 \mathrm{kDa})$, or glycerinaldehyde-3-phosphate dehydrogenase (GAPDH) $(38 \mathrm{kDa})$ in lysates of BA/F3 cells transduced with empty vector, BCR-ABL1 or BCR-ABL1 ${ }^{\mathrm{T} 315 \mathrm{I}}$. The immunoblot is representative of three independent experiments. b Immunoblot showing the expression of ILK pS246 $(65 \mathrm{kDa})$, ILK $(51 \mathrm{kDa})$, or GAPDH $(38 \mathrm{kDa})$ in lysates of BA/ $\mathrm{F} 3$ cells transduced with BCR-ABL1- or BCR-ABL1 ${ }^{\mathrm{T} 315 \mathrm{I}}$-expressing retrovirus treated with vehicle, $60 \mathrm{nM}$ ponatinib or $750 \mathrm{nM}$ imatinib for $4 \mathrm{~h}$. The immunoblot is representative of three independent experiments. c Immunofluorescence of BA/F3 cells transduced with

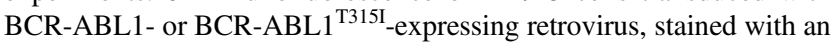
antibody to ILK (red) or integrin $\beta 3$ (green). The nuclei are counterstained with DAPI. The images are representative of three experiments. The scale bar represents $50 \mu \mathrm{m}$. d Coimmunoprecipitation (IP) of lysates of $\mathrm{BA} / \mathrm{F} 3$ cells transduced with BCR-ABL1 or BCRABL1 ${ }^{\text {T315I }}$ with an anti-integrin $\beta 3$ (ITGB3) antibody. The immunoblot was performed with an antibody to integrin $\beta 3(92 \mathrm{kDa})$ and ILK $(51 \mathrm{kDa})$. e, f Leukocyte counts $(\mathrm{WBC}) \times 10^{3}$ per $\mu$ in peripheral blood $\left(P=0.0018\right.$ for BCR-ABL1 ${ }^{\mathrm{T} 315 \mathrm{I}+}$; $t$-test, $\left.n=8-10\right)(\mathbf{e})$ and Kaplan-Meier-style survival curve (f) of BALB/c recipient mice transplanted with bone marrow cotransduced with BCR-ABL1- or BCR-ABL1 ${ }^{\mathrm{T} 315 \mathrm{I}}$-expressing retrovirus and Scrambled or Ilk shRNAexpressing lentivirus $\left(P=0.0476\right.$ for BCR-ABL1 ${ }^{\mathrm{T} 315 \mathrm{I}+}$, Log-rank test, $n=10$ ). g Kaplan-Meier-style survival curve of BALB/c recipient mice transplanted with bone marrow cotransduced with BCR-ABL1or $\mathrm{BCR}-\mathrm{ABL} 1^{\mathrm{T} 315 \mathrm{I}}$-expressing retrovirus and a lentivirus expressing inducible nontarget control or $I l k$ shRNA $(P=0.0028$ for BCR$\mathrm{ABL}^{\mathrm{T} 315 \mathrm{I}+}$ and $P=0.0386$ for BCR-ABL1, Log-rank test, $\left.n=10\right)$. $50 \mathrm{mg} / \mathrm{kg}$ of doxcyclin to induce shRNA-expression was administered intraperitoneally to recipient mice on days 8, 9, 10, and 12 after transplantation. h Immunofluorescence of normal wildtype (WT) 3T3 fibroblasts or $3 \mathrm{~T} 3$ fibroblasts transduced with BCR-ABL1- or BCR$\mathrm{ABL1}^{\mathrm{T} 315 \mathrm{I}}$-expressing retrovirus and Scrambled or Ilk shRNAexpressing lentivirus. The nuclei are counterstained with DAPI. The images are representative of four independent experiments. i Immunohistochemistry for fibronectin (detected by immunoperoxidase using yellow-brown horseradish-peroxidase chromogen) on bones of representative $\mathrm{BALB} / \mathrm{c}$ recipient mice transplanted with BCR-ABL1or BCR-ABL1 ${ }^{\mathrm{T} 315 \mathrm{I}}$ - and sh Scrambled or sh Ilk-cotransduced bone marrow. j Western blot showing the expression of ILK pS246 (65 $\mathrm{kDa})$, ILK $(51 \mathrm{kDa})$, AKT pS473 $(62 \mathrm{kDa})$, or GAPDH $(38 \mathrm{kDa})$ as loading control in lysates of BA/F3 cells transduced with BCR$\mathrm{ABL}^{\mathrm{T} 315 \mathrm{I}}$ and treated with vehicle, $50 \mathrm{nM} \mathrm{Cpd} 22,60 \mathrm{nM}$ ponatinib, or $40 \mathrm{nM}$ wortmannin for $6 \mathrm{~h}$.

(Fig. S7B) [23] or MLL-AF9 ${ }^{+}$AML (Fig. S7C) [20, 42] did not lead to significant differences in survival. Taken together, these data suggest that fibronectin may be involved in regulating the progression of BCR-ABL1 ${ }^{\mathrm{T} 315 \mathrm{I}+} \mathrm{CML}$.

\section{Treatment with the ILK inhibitor Cpd22 and ponatinib prolongs survival in BCR-ABL1 ${ }^{\text {T3151+ }} \mathrm{CML}$}

In order to test whether inhibition of ILK may have a role for the treatment of $\mathrm{BCR}-\mathrm{ABL} 1^{\mathrm{T} 315 \mathrm{I}}+\mathrm{CML}$, we treated mice with BCR-ABL1 ${ }^{\mathrm{T} 315 \mathrm{I}+} \mathrm{CML}$ with vehicle, ponatinib, the ILK inhibitor Cpd22 [43], or the combination of Cpd22 and ponatinib. Cotreatment with the ILK inhibitor Cpd22 and ponatinib led to a modest, but significant prolongation of survival compared with treatment with ponatinib alone $(P=0.0036$; Fig. $7 a)$. Consistent with a presumed role of ILK in fibronectin deposition, treatment with Cpd22 alone, ponatinib alone, or the combination of Cpd22 and ponatinib increased the levels of fibronectin in bone sections (Fig. 7b). Treatment with $\mathrm{Cpd} 22$ or ponatinib increased the percentage of integrin $\beta 3^{+} \mathrm{BCR}-$ $\mathrm{ABL}^{+}{ }^{+}$(Fig. S8A) and BCR-ABL1 ${ }^{\mathrm{T} 315 \mathrm{I}+}$ (Fig. S8B) cells. Integrin $\beta 3$ clusters per area, which fortify the interaction with focal adhesosomes [44], also significantly increased by treatment of BCR-ABL1 ${ }^{\mathrm{T} 315 \mathrm{I}+}$ cells with $\mathrm{Cpd} 22(P=$ 0.0051 , Fig. S8C). In summary, inhibition of ILK with Cpd22 in combination with ponatinib prolongs survival in BCR-ABL1 ${ }^{\mathrm{T} 315 \mathrm{I}+} \mathrm{CML}$. The benefit of ILK inhibition may lie in the combination of increasing fibronectin levels in the BMM, as well as in the further increase of integrin $\beta 3$ on leukemia cells.

\section{The fibronectin/integrin $\beta 3 /$ ILK-axis in human BCR- $\mathrm{ABL1}^{\mathrm{T} 3151+} \mathrm{CML}$ cells}

Validating our results in the human setting, we demonstrated increased levels of integrin $\beta 3(P=0.025$, Figs. 7c and S8D-E), increased migration $(P=0.0439$, Fig. $7 \mathrm{~d})$ and adhesion of $\mathrm{K} 562^{\mathrm{T} 315 \mathrm{I}}(P=0.0288$, Fig. 7e) compared with K562 cells [45]. Transplantation of K562 versus K562 ${ }^{\mathrm{T} 315 \mathrm{I}}$ cells into NOD SCID interleukin-2 receptor $\gamma$ (NSG) knockout mice led to increased percentages of human $\mathrm{CD} 45^{+}$leukocytes in peripheral blood $(P=0.0133$, Fig. $7 \mathrm{f})$ and $\mathrm{BM}(P=0.0357$, Fig. $7 \mathrm{~g})$ in recipients of $\mathrm{K}_{562} 2^{\mathrm{T} 315 \mathrm{I}}$ cells. Similar, but less striking results were observed after transplantation of KCL-22 $2^{\mathrm{T} 315 \mathrm{I}}$ compared with KCL-22 cells (Fig. S8F-G). Treatment of NSG mice transplanted with $\mathrm{K} 562^{\mathrm{T} 315 \mathrm{I}}$ cells with $\mathrm{Cpd} 22$, ponatinib or their combination led to a trend towards reduced engraftment of human $\mathrm{CD} 45^{+}$leukocytes compared with vehicle (Figs. 7h and $\mathrm{S} 8 \mathrm{H})$. Furthermore, fibronectin levels were significantly reduced in bone sections $(P=0.043$; Fig. $7 \mathrm{i}, \mathrm{j})$ and levels of ILK, ILK pS246 and integrin $\beta 3$ were higher in leukemia cell samples from most patients with $\mathrm{BCR}-\mathrm{ABL1}^{\mathrm{T} 315 \mathrm{I}+}$ compared with $\mathrm{BCR}^{-\mathrm{ABL}^{+}}{ }^{\mathrm{CML}}$, though interpatient variability was observed (Figs. $7 \mathrm{k}$ and S8I). Lastly, transplantation of human BCR-ABL1 ${ }^{+}$versus BCRABL1T315I ${ }^{+}$CML cells into NSG mice treated in pairs with vehicle or fibronectin led to a nonsignificant reduction of the engraftment of human $\mathrm{CD} 45^{+}$leukocytes in the majority of treated versus untreated mouse pairs (Fig. 71). Treatment with fibronectin also led to a reduction of oncogene transcript levels in 2/4 (50\%) recipients of human $\mathrm{BCR}-\mathrm{ABL1}^{+}$and $4 / 5(80 \%)$ recipients of BCR-ABL1 ${ }^{\mathrm{T} 315 \mathrm{I}}+$ CML cells (Fig. $7 \mathrm{~m}$ ). In summary, our data with human material suggest that the described link between fibronectin/ integrin $\beta 3 / \mathrm{ILK}$ may also be applicable to human BCR$\mathrm{ABL1}^{\mathrm{T} 315 \mathrm{I}+} \mathrm{CML}$. 
A

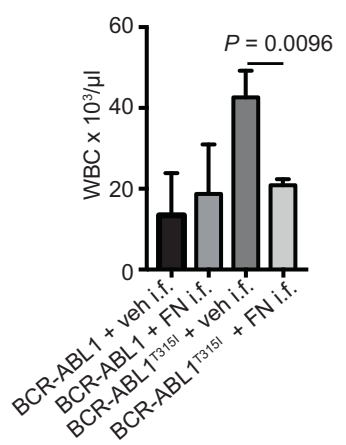

B

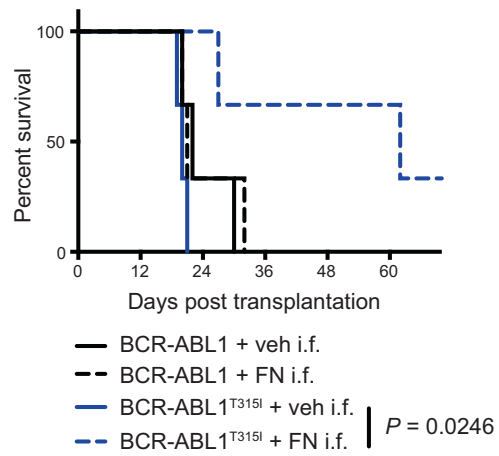

C

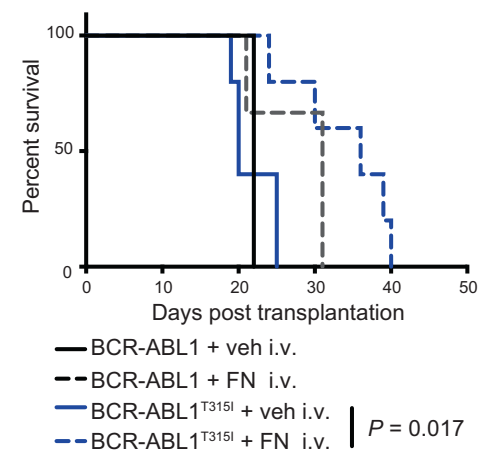

Fig. 6 Treatment with fibronectin prolongs survival in BCRABL1 $^{\text {T315I }+}$ CML. a-b Leukocyte counts $(\mathrm{WBC}) \times 10^{3}$ per $\mu \mathrm{l}$ in peripheral blood $\left(P=0.0096\right.$ for BCR-ABL1 ${ }^{\mathrm{T} 315 \mathrm{I}+} ; t$-test, $\left.n=3\right)(\mathbf{a})$ and Kaplan-Meier-style survival curve (b) of BALB/c recipient mice transplanted with bone marrow transduced with BCR-ABL1 (black)or BCR-ABL1 ${ }^{\mathrm{T} 315 \mathrm{I}}$ (blue)-expressing retrovirus and treated with intrafemoral (i.f.) administrations of vehicle (solid line) or $50 \mu \mathrm{g}$ fibronectin resuspended in $50 \mu \mathrm{l}$ PBS (dashed line) per mouse per injection on days 0,1 , and $2\left(P=0.0246\right.$ for BCR-ABL1 ${ }^{\mathrm{T} 315 \mathrm{I}+}, \mathrm{Log}-$

\section{Discussion}

In continuation of previous studies $[15,16]$ we demonstrate here that the increased oncogenicity of the $B C R-A B L 1^{T 315 I}$ mutation is at least partly due to differences in the interaction with the BMM and its remodeling compared with native $B C R-A B L 1$. BCR-ABL1 ${ }^{\mathrm{T} 315 \mathrm{I}+}$ cells differ from $\mathrm{BCR}$ $\mathrm{ABL1}^{+}$cells with regards to the actin cytoskeleton, migratory properties, expression of integrin $\beta 3$, the levels and phosphorylation of FAK and ILK, as well as ILKdependent deposition of fibronectin in the BMM. Further increased expression of integrin $\beta 3$ led to increased myeloid maturation and a deceleration of leukemic progression, while a decrease of fibronectin expression in BCR-ABL1 ${ }^{+}$ cells accelerated the disease similar to BCR-ABL1 ${ }^{\mathrm{T} 315 \mathrm{I}+}$ CML. Administration of fibronectin decelerated BCR$\mathrm{ABL1}^{\mathrm{T} 315 \mathrm{I}+}$ disease. In summary, our data suggest that interactions with proteins of the ECM influence CML progression and that therapeutic manipulation of the levels of ECM proteins may be beneficial in (resistant) CML.

Our data extend the observation that integrin $\beta 3$ is essential for leukemogenesis and influences outcome in AML [34] and suggest that integrin $\beta 3$ - possibly via its interaction with ECM proteins such as fibronectin-may be involved in myeloid maturation, as suggested for integrin $\beta 1$ [46].

Our findings on the differential location of normal HSPC and $\mathrm{BCR}-\mathrm{ABL1} 1^{+}$or $\mathrm{BCR}-\mathrm{ABL1} 1^{\mathrm{T} 315 \mathrm{I}+}$ LIC are consistent with a previous study on the distinct physical engagement of the BMM by MLL-AF9 ${ }^{+}$AML cells, which is dependent on the degree of leukemic progression [18]. Our results further suggest that niche location of malignant cells may rank test). At the time of transplant (day 0), the leukemia-initiating cells had been resuspended in vehicle or fibronectin. c Kaplan-Meierstyle survival curve of BALB/c recipient mice transplanted with bone marrow transduced with BCR-ABL1 (black)- or BCR-ABL1 ${ }^{\mathrm{T} 315 \mathrm{I}}$ (blue)-expressing retrovirus and treated with intravenous (i.v.) administrations of vehicle (solid line) or $200 \mu \mathrm{g}$ fibronectin per mouse per injection (dashed line) on days 9,10 , and 12 ( $P=0.017$ for BCR$\mathrm{ABL1}^{\mathrm{T} 315 \mathrm{I}+}$, Log-rank test, $\left.n=3-5\right)$.

influence survival, possibly also in response to TKI treatment.

The involvement of ILK in the pathophysiology of BCR$\mathrm{ABL1}^{\mathrm{T} 315 \mathrm{I}+}$ (and $\mathrm{BCR}-\mathrm{ABL} 1^{+}$) $\mathrm{CML}$, given its linkage to the cytoplasmic domains of integrin $\beta 1$ and $\beta 3$, its support of scaffolding proteins [40] and its known role in the deposition of fibronectin by epithelial cells [47] — though opposite from our results in hematopoietic cells-and other ECM proteins [48] was not surprising and may be context dependent. The expression and activity of ILK is known to be increased in several epithelial cancers [49], where it may also contribute to chemoresistance via regulation of adhesion to fibronectin [50]. In addition, ILK has been postulated to be a novel target in solid cancers [49] and leukemia [51], though a connection to the BMM was not established. In our work, treatment with $\mathrm{Cpd} 22$ and ponatinib significantly prolonged survival in BCR-ABL1 $1^{\mathrm{T} 315 \mathrm{I}} \mathrm{CML}$ compared with ponatinib alone.

Fibronectin is overexpressed in certain cancers and contributes to the tumorigenic process [52] contrary to our findings in BCR-ABL1 ${ }^{\mathrm{T} 315 \mathrm{I}+} \mathrm{CML}$, where decreased levels of fibronectin exacerbate leukemia progression. In hematopoiesis, fibronectin supports the growth of HSPC $[53,54]$, whereas fibronectin may inhibit the proliferation of B-ALL cells in vitro [55]. Our data suggest that administration of fibronectin-or an increase of fibronectin levels via inhibition of ILK - may be beneficial in BCR-ABL1 ${ }^{\mathrm{T} 315 \mathrm{I}+} \mathrm{CML}$, for which limited therapies or only treatments with significant side effects exist. Although fibronectin did not lead to a significant survival prolongation in $\mathrm{BCR}^{-\mathrm{ABL} 1^{+}}{ }^{+} \mathrm{B}-\mathrm{ALL}$ or $\mathrm{MLL}^{-\mathrm{AF}}{ }^{+}$ AML, it is likely that this may have been due to 
A

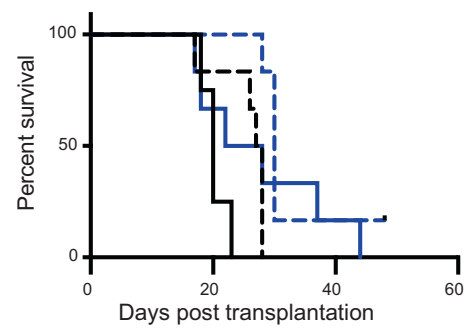

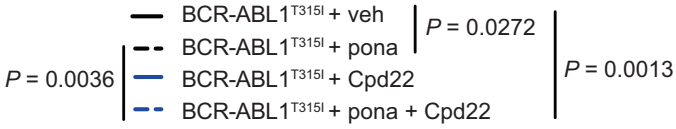
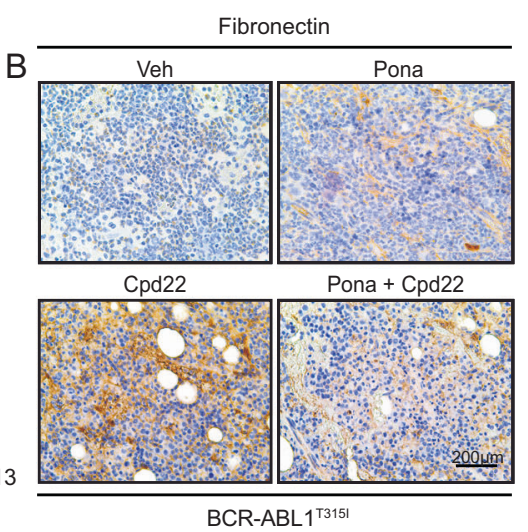

C

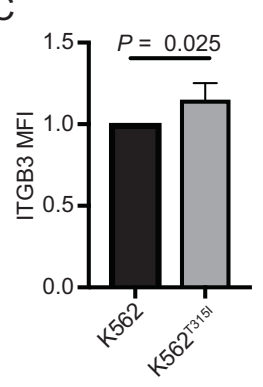

G

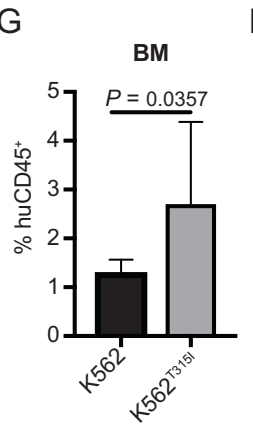

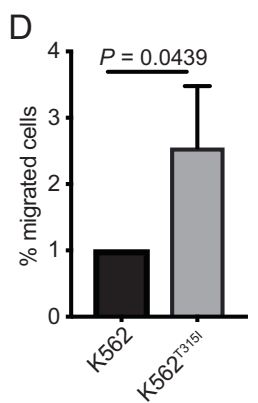

$\mathrm{H}$

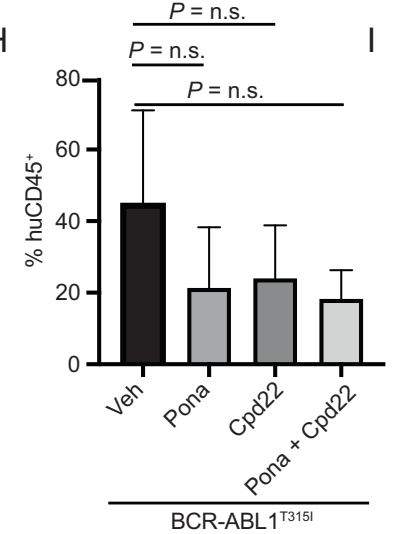

E

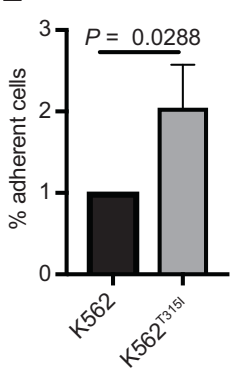

$\mathrm{F}$

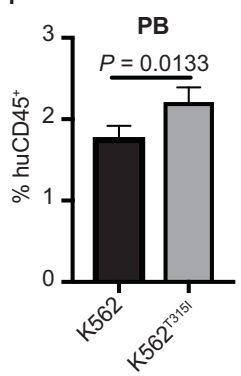

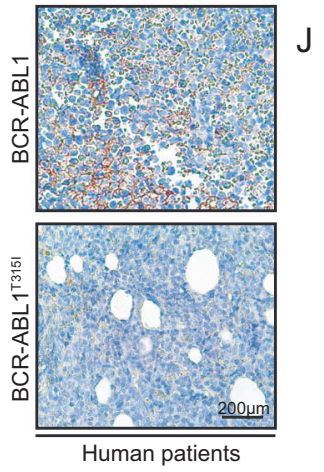

$\mathrm{J}$

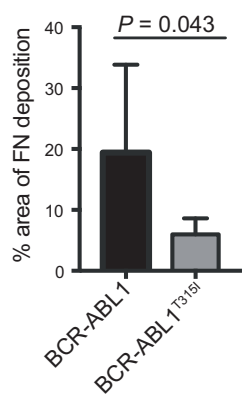

K

L

M
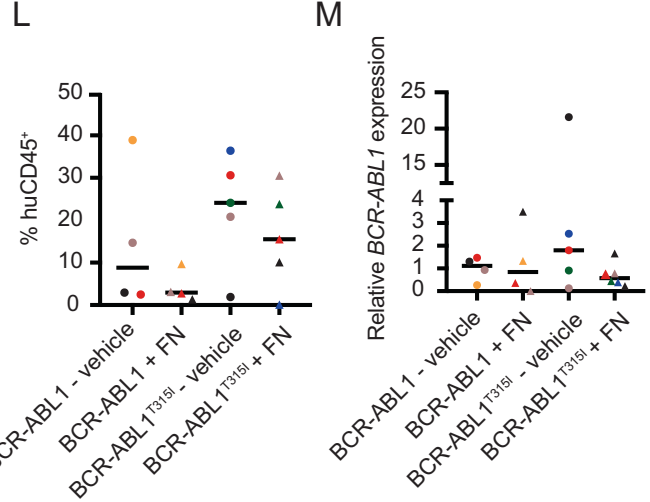

suboptimal dosing and timing of the administration of fibronectin, whose high purchasing costs were prohibitive of further exploration in this study.
In conclusion, we have demonstrated that a point mutation in the kinase domain of $B C R-A B L 1$, which leads to imatinib resistance, in our models has altered biological 
Fig. 7 Levels of fibronectin are decreased and levels of integrin $\beta 3$ and ILK are increased in human $B C R-A B L 1^{T 315 I+}$ CML cells. a Kaplan-Meier-style survival curve of $\mathrm{BALB} / \mathrm{c}$ recipient mice transplanted with bone marrow transduced with BCR-ABL1 ${ }^{\mathrm{T} 315 \mathrm{I}}$ expressing retrovirus and treated with vehicle (solid black line), $20 \mathrm{mg} /$ $\mathrm{kg}$ ponatinib (dashed black line), $15 \mathrm{mg} / \mathrm{kg}$ Cpd22 (solid blue line), or ponatinib and $\mathrm{Cpd} 22$ (blue dashed line) (doses as above) $(P=0.0036$ for ponatinib versus ponatinib plus Cpd22, Log-rank test, $n=5-6$ ). Ponatinib was given daily on days 9-22, while Cpd22 was given daily on days 9-14 and every other day on days 14-22 after transplantation. b Immunohistochemistry for fibronectin (detected by immunoperoxidase using yellow-brown horseradish-peroxidase chromogen) on bones of BALB/c recipient mice transplanted with BCR-ABL1 ${ }^{\mathrm{T} 315 \mathrm{I}_{-}}$ transduced bone marrow treated with vehicle, ponatinib, $\mathrm{Cpd} 22$, or the combination of ponatinib and $\mathrm{Cpd} 22$ as in (a). c Relative mean fluorescence intensity (MFI) of integrin $\beta 3$ (ITGB3) on K562 (black) or $\mathrm{K} 562^{\mathrm{T} 315 \mathrm{I}}$ (gray) cells $(P=0.025 ; t$-test, $n=3)$. d Percentage of $\mathrm{K} 562$ (black) or K562 ${ }^{\mathrm{T} 315 \mathrm{I}}$ (gray) cells which migrated to the bottom chamber containing MS-5 stroma cells in medium containing $10 \%$ serum in a transwell migration assay after $8 \mathrm{~h}(P=0.0439 ; t$-test, $n=$ 4). In total, $10^{5} \mathrm{~K} 562$ cells and 30,000 MS-5 cells had been plated. e Percentage of $\mathrm{K} 562$ (black) or $\mathrm{K} 562^{\mathrm{T} 315 \mathrm{I}}$ (gray) cells adhering to MS-5 stroma cells in vitro $(P=0.0288 ; t$-test, $n=4)$. In total, $10^{5}$ K562 cells were plated on top of 30,000 MS-5 stroma cells. Cells had been allowed to adhere for $12 \mathrm{~h}$. Percentage of human $\mathrm{CD}^{+} 5^{+}$leukocytes in the peripheral blood (PB) (f) or bone marrow (BM) (g) of NOD SCID interleukin-2 receptor $\gamma$ knockout (NSG) mice transplanted with $3 \times 10^{6} \mathrm{~K} 562$ (black) or K562 ${ }^{\mathrm{T} 315 \mathrm{I}}$ (gray) cells on day 38 after transplantation. The mice had not been irradiated $(P=0.0133$ for PB and $P=0.0357$ for BM; $t$-test, $n=3-5$ ). h Percentage of human $\mathrm{CD}_{4} 5^{+}$leukocytes in the bone marrow of NOD SCID interleukin-2 receptor $\gamma$ knockout (NSG) mice transplanted with $3 \times 10^{6} \mathrm{~K}_{562} 2^{\mathrm{T} 315 \mathrm{I}}$ cells treated with vehicle, ponatinib, $\mathrm{Cpd} 22$ or ponatinib plus $\mathrm{Cpd} 22$ as in (a) at the time of death. The results are not significant $(n=4-7)$. Immunohistochemistry for fibronectin (detected by immunoperoxidase using yellow-brown horseradish-peroxidase chromogen) (i) and quantification of the area of fibronectin $(\mathrm{FN})$ staining $(\mathbf{j})$ in bone sections of patients with $\mathrm{BCR}-\mathrm{ABL1}^{+}$(black) or BCR-ABL1 ${ }^{\mathrm{T} 315 \mathrm{I}+}$ (gray) CML $(n=4-11)$. $\mathbf{k}$ Immunoblot showing the expression of ILK pS246 (65 kDa), ILK (51 kDa), integrin $\beta 3$ (92 kDa), or GAPDH (38 $\mathrm{kDa}$ ) as loading control in lysates of leukocytes from the bone marrow or peripheral blood of patients with $\mathrm{BCR}-\mathrm{ABL1}^{+}$or $\mathrm{BCR}-\mathrm{ABL} 1^{\mathrm{T} 315 \mathrm{I}+}$ CML. Percentage of engraftment of human CD45 ${ }^{+}\left(\mathrm{hCD} 45^{+}\right)$leukocytes (1), or relative levels of $B C R-A B L 1^{+}$or $B C R-A B L 1^{T 315 I+}$ engraftment in BM aspirates from individual NSG recipients of primary human CML samples (peripheral blood or BM) on day 28 after transplantation $(n=4-5)(\mathbf{m})$. The recipient mice were treated with either saline or $200 \mu \mathrm{g} /$ dose fibronectin on days $9,10,11,13$, and 15 after transplantation. Recipients of peripheral blood or BM grafts from the same human CML sample are indicated by the same individual symbols. Each human patient sample was transplanted into one vehicle- and two to three fibronectin-treated recipient mice.

activity and is associated with more aggressive disease due to altered interactions with the BMM via the fibronectin-integrin $\beta 3$-ILK pathway. We confirmed altered, though variable expression levels and targetability of these proteins in human BCR-ABL1 ${ }^{\mathrm{T} 315 \mathrm{I}}{ }^{\mathrm{C}} \mathrm{CML}$ cells. This may also explain the accelerated phenotype in humans. These altered interactions and specifically decreased levels of fibronectin or ILK in BCR$\mathrm{ABL1}{ }^{\mathrm{T} 315 \mathrm{I}+} \mathrm{CML}$ are valuable targets. It is to be hoped that modification of this pathway will lead to the development of novel therapies for imatinib-resistant CML and, hopefully, other leukemias.

Acknowledgements The authors thank Joel A. Spencer, Cristina Lo Celso, and Charles P. Lin for assistance with in vivo microscopy. This work was supported by the LOEWE Center for Cell and Gene Therapy Frankfurt (CGT) and institutional funds of the Georg-Speyer-Haus to DSK. The Georg-Speyer-Haus is funded jointly by the German Federal Ministry of Health (BMG) and the Ministry of Higher Education, Research and the Arts of the State of Hessen (HMWK). The LOEWE Center for Cell and Gene Therapy Frankfurt is funded by HMWK, reference number: III L 4-518/17.004 (2010).

Author contributions RK designed and carried out experiments, analyzed the data and reviewed the paper. RSP, CZ, MaMe, and JN assisted with experiments. MeMe and VM designed and carried out experiments and analyzed the data. NR assisted with mouse work. MSD and MH performed and analyzed super-resolution microscopy experiments. FS provided expertise in molecular biology. MT, KA, and TI generated the K562 ${ }^{\mathrm{T} 315 \mathrm{I}}$ cells. TO designed and carried out the mass spectrometry experiments and analyzed the data. FEN and HP contributed patient samples. HMK contributed patient material, stained, and analyzed slides. RVE performed the initial murine survival experiments on imatinib-resistant mutants. DSK designed experiments, supervised the project, analyzed data, and wrote the paper.

\section{Compliance with ethical standards}

Conflict of interest RK, MeMe, and DSK hold patent no. WO2018/ 046666 for the use of fibronectin and ILK-inhibitors in leukemia.

Publisher's note Springer Nature remains neutral with regard to jurisdictional claims in published maps and institutional affiliations.

Open Access This article is licensed under a Creative Commons Attribution 4.0 International License, which permits use, sharing, adaptation, distribution and reproduction in any medium or format, as long as you give appropriate credit to the original author(s) and the source, provide a link to the Creative Commons license, and indicate if changes were made. The images or other third party material in this article are included in the article's Creative Commons license, unless indicated otherwise in a credit line to the material. If material is not included in the article's Creative Commons license and your intended use is not permitted by statutory regulation or exceeds the permitted use, you will need to obtain permission directly from the copyright holder. To view a copy of this license, visit http://creativecommons. org/licenses/by/4.0/.

\section{References}

1. Dean M, Fojo T, Bates S. Tumour stem cells and drug resistance. Nat Rev Cancer. 2005;5:275-84.

2. Zheng HC. The molecular mechanisms of chemoresistance in cancers. Oncotarget. 2017;8:59950-64.

3. Krause DS, Van Etten RA. Tyrosine kinases as targets for cancer therapy. N Engl J Med. 2005;353:172-87.

4. Junttila MR, de Sauvage FJ. Influence of tumour microenvironment heterogeneity on therapeutic response. Nature. 2013;501:346-54.

5. Krause DS, Scadden DT. A hostel for the hostile: the bone marrow niche in hematologic neoplasms. Haematologica. 2015;100:1376-87. 
6. Soverini S, Mancini M, Bavaro L, Cavo M, Martinelli G. Chronic myeloid leukemia: the paradigm of targeting oncogenic tyrosine kinase signaling and counteracting resistance for successful cancer therapy. Mol Cancer. 2018;17:49.

7. Buchdunger E, Zimmermann J, Mett H, Meyer T, Müller M, Druker BJ, et al. Inhibition of the Abl protein-tyrosine kinase in vitro and in vivo by a 2-phenylaminopyrimidine derivative. Cancer Res. 1996;56:100-4.

8. Gorre ME, Mohammed M, Ellwood K, Hsu N, Paquette R, Rao $\mathrm{PN}$, et al. Clinical resistance to STI-571 cancer therapy caused by $B C R-A B L$ gene mutation or amplification. Science. 2001;293:876-80.

9. Shah NP, Nicoll JM, Nagar B, Gorre ME, Paquette RL, Kuriyan J, et al. Multiple BCR-ABL kinase domain mutations confer polyclonal resistance to the tyrosine kinase imatinib (STI571) in chronic phase and blast crisis chronic myeloid leukemia. Cancer Cell. 2002;2:117-25.

10. Soverini S, Branford S, Nicolini FE, Talpaz M, Deininger MW, Martinelli $\mathrm{G}$, et al. Implications of BCR-ABL1 kinase domainmediated resistance in chronic myeloid leukemia. Leuk Res. 2014;38:10-20.

11. Nicolini FE, Corm S, Lê QH, Sorel N, Hayette S, Bories D, et al. Mutation status and clinical outcome of 89 imatinib mesylateresistant chronic myelogenous leukemia patients: a retrospective analysis from the French intergroup of CML (Fi( $\phi)$-LMC GROUP). Leukemia. 2006;20:1061-6.

12. Branford S, Melo JV, Hughes TP. Selecting optimal second-line tyrosine kinase inhibitor therapy for chronic myeloid leukemia patients after imatinib failure: does the BCR-ABL mutation status really matter? Blood. 2009;114:5426-35.

13. Nicolini FE, Ibrahim AR, Soverini S, Martinelli G, Müller MC, Hochhaus A, et al. The BCR-ABLT315I mutation compromises survival in chronic phase chronic myelogenous leukemia patients resistant to tyrosine kinase inhibitors, in a matched pair analysis. Haematologica. 2013;98:1510-6.

14. Balabanov S, Braig M, Brümmendorf TH. Current aspects in resistance against tyrosine kinase inhibitors in chronic myelogenous leukemia. Drug Discov Today Technol. 2014;11:89-99.

15. Skaggs BJ, Gorre ME, Ryvkin A, Burgess MR, Xie Y, Han Y, et al. Phosphorylation of the ATP-binding loop directs oncogenicity of drug-resistant BCR-ABL mutants. Proc Natl Acad Sci USA. 2006;103:19466-71.

16. Griswold IJ, MacPartlin M, Bumm T, Goss VL, O'Hare T, Lee $\mathrm{KA}$, et al. Kinase domain mutants of Bcr-Abl exhibit altered transformation potency, kinase activity, and substrate utilization, irrespective of sensitivity to imatinib. Mol Cell Biol. 2006;26:6082-93.

17. Lo Celso C, Fleming HE, Wu JW, Zhao CX, Miake-Lye S, Fujisaki J, et al. Live-animal tracking of individual haematopoietic stem cells in their niche. Nature. 2009;457:92-6.

18. Lane SW, Wang YJ, Lo Celso C, Ragu C, Bullinger L, Sykes SM, et al. Differential niche and Wnt requirements during acute myeloid leukemia progression. Blood. 2011;118:2849-56.

19. Hu Y, Swerdlow S, Duffy TM, Weinmann R, Lee FY, Li S. Targeting multiple kinase pathways in leukemic progenitors and stem cells is essential for improved treatment of $\mathrm{Ph}+$ leukemia in mice. Proc Natl Acad Sci USA. 2006;103:16870-5.

20. Krause DS, Fulzele K, Catic A, Sun CC, Dombkowski D, Hurley MP, et al. Differential regulation of myeloid leukemias by the bone marrow microenvironment. Nat Med. 2013;19:1513-7.

21. Wylie AA, Schoepfer J, Jahnke W, Cowan-Jacob SW, Loo A, Furet $\mathrm{P}$, et al. The allosteric inhibitor ABL001 enables dual targeting of BCR-ABL1. Nature. 2017;543:733-7.

22. Li S, Ilaria RL, Million RP, Daley GQ, Van Etten RA. The P190, $\mathrm{P} 210$, and $\mathrm{P} 230$ forms of the $B C R / A B L$ oncogene induce a similar chronic myeloid leukemia-like syndrome in mice but have different lymphoid leukemogenic activity. J Exp Med. 1999;189:1399-412.

23. Krause DS, Lazarides K, von Andrian UH, Van Etten RA. Requirement for CD44 in homing and engraftment of BCR-ABLexpressing leukemic stem cells. Nat Med. 2006;12:1175-80.

24. Hamilton A, Helgason GV, Schemionek M, Zhang B, Myssina S, Allan EK, et al. Chronic myeloid leukemia stem cells are not dependent on Bcr-Abl kinase activity for their survival. Blood. 2012;119:1501-10.

25. Nardi V, Naveiras O, Azam M, Daley GQ. ICSBP-mediated immune protection against BCR-ABL-induced leukemia requires the CCL6 and CCL9 chemokines. Blood. 2009;113:3813-20.

26. Cheng K, Kurzrock R, Qiu X, Estrov Z, Ku S, Dulski KM, et al. Reduced focal adhesion kinase and paxillin phosphorylation in BCR-ABL-transfected cells. Cancer. 2002;95:440-50.

27. Gotoh A, Miyazawa K, Ohyashiki K, Tauchi T, Boswell HS, Broxmeyer HE, et al. Tyrosine phosphorylation and activation of focal adhesion kinase (p125FAK) by BCR-ABL oncoprotein. Exp Hematol. 1995;23:1153-9.

28. Van Etten RA, Jackson P, Baltimore D. The mouse type IV c- $a b l$ gene product is a nuclear protein, and activation of transforming ability is associated with cytoplasmic localization. Cell. 1989;58:669-78.

29. Weisberg E, Sattler M, Ewaniuk DS, Salgia R. Role of focal adhesion proteins in signal transduction and oncogenesis. Crit Rev Oncog. 1997;8:343-58.

30. Roa-Espitia AL, Hernández-Rendón ER, Baltiérrez-Hoyos R, Muñoz-Gotera RJ, Cote-Vélez AIJ, et al. Focal adhesion kinase is required for actin polymerization and remodeling of the cytoskeleton during sperm capacitation. Biol Open. 2016;5:1189-99.

31. Fabry B, Klemm AH, Kienle S, Schäffer TE. WHG Focal adhesion kinase stabilizes the cytoskeleton. Biophys J. 2011;101:2131-8

32. Parsons JT. Focal adhesion kinase: the first ten years. J Cell Sci. 2003;116:1409-16.

33. Corbel C, Vaigot P, Salaün J. (alpha)Ilb Integrin, a novel marker for hemopoietic progenitor cells. Int J Dev Biol. 2005;49:279-84.

34. Miller PG, Al-Shahrour F, Hartwell KA, Chu LP, Jaras M, Puram $\mathrm{RV}$, et al. In vivo RNAi screening identifies a leukemia-specific dependence on integrin beta 3 signaling. Cancer Cell. 2013;24:45-58.

35. Sauer M, Heilemann M. Single-molecule localization microscopy in eukaryotes. Chem Rev. 2017;117:7478-509.

36. Kawelke N, Vasel M, Sens C, Au A, Dooley S, Nakchbandi IA. Fibronectin protects from excessive liver fibrosis by modulating the availability of and responsiveness of stellate cells to active TGF- $\beta$. PLoS ONE. $2011 ; 6: \mathrm{e} 28181$.

37. Ghatak S, Morgner J, Wickström SA. ILK: a pseudokinase with a unique function in the integrin-actin linkage. Biochem Soc Trans. 2013;41:995-1001.

38. Guo L, Wu C. Regulation of fibronectin matrix deposition and cell proliferation by the PINCH-ILK-CH-ILKBP complex. FASEB J. 2002;16:1298-1300.

39. Gagné D, Groulx JF, Benoit YD, Basora N, Herring E, Vachon $\mathrm{PH}$, et al. Integrin-linked kinase regulates migration and proliferation of human intestinal cells under a fibronectin-dependent mechanism. J Cell Physiol. 2010;222:387-400.

40. Widmaier M, Rognoni E, Radovanac K, Azimifar SB, Fässler R. Integrin-linked kinase at a glance. J Cell Sci. 2012;125:1839-43.

41. Kharas MG, Janes MR, Scarfone VM, Lilly MB, Knight ZA, Shokat KM, et al. Ablation of PI3K blocks BCR-ABL leukemogenesis in mice, and a dual $\mathrm{PI} 3 \mathrm{~K} / \mathrm{mTOR}$ inhibitor prevents expansion of human BCR-ABL+ leukemia cells. J Clin Investig. 2008;118:3038-50.

42. Krivtsov AV, Twomey D, Feng Z, Stubbs MC, Wang Y, Faber J, et al. Transformation from committed progenitor to 
leukaemia stem cell initiated by MLL-AF9. Nature. 2006; 442:818-22.

43. Ahmed AU, Yim $\mathrm{HCH}$, Alorro M, Ernst M, Williams BRG. Integrin-linked kinase expression in myeloid cells promotes inflammatory signaling during experimental colitis. J Immunol. 2017; pii: ji1700125. https://doi.org/10.4049/jimmunol.1700125. [Epub ahead of print].

44. Kim SH, Turnbull J, Guimond S. Extracellular matrix and cell signalling: the dynamic cooperation of integrin, proteoglycan and growth factor receptor. J Endocrinol. 2011;209:139-51.

45. Tamai M, Inukai T, Kojika S, Abe M, Kagami K, Harama D, et al. T315I mutation of BCR-ABL1 into human Philadelphia chromosome-positive leukemia cell lines by homologous recombination using the CRISPR/Cas9 system. Sci Rep. 2018;8:9966.

46. Kerst JM, Sanders JB, Slaper-Cortenbach IC, Doorakkers MC, Hooibrink B, van Oers RH, et al. Alpha 4 beta 1 and alpha 5 beta 1 are differentially expressed during myelopoiesis and mediate the adherence of human CD34+ cells to fibronectin in an activationdependent way. Blood. 1993;81:344-51.

47. Wu C, Keightley SY, Leung-Hagesteijn C, Radeva G, Coppolino $\mathrm{M}$, Goicoechea $\mathrm{S}$, et al. Integrin-linked protein kinase regulates fibronectin matrix assembly, E-cadherin expression, and tumorigenicity. J Biol Chem. 1998;273:528-36.

48. Morgner J, Ghatak S, Jakobi T, Dieterich C, Aumailley M, Wickström SA. Integrin-linked kinase regulates the niche of quiescent epidermal stem cells. Nat Comm. 2015;8:8198.

49. Hannigan G, Troussard AA, Dedhar S. Integrin-linked kinase: a cancer therapeutic target unique among its ILK. Nat Rev Cancer. 2005;5:51-63.
50. Nakagawa Y, Nakayama H, Nagata M, Yoshida R, Kawahara K, Hirosue A, et al. Overexpression of fibronectin confers cell adhesion-mediated drug resistance (CAM-DR) against 5-FU in oral squamous cell carcinoma cells. Int $\mathrm{J}$ Oncol. 2014;44:1376-84.

51. de la Puente P, Weisberg E, Muz B, Nonami A, Luderer M, Stone RM, et al. Identification of ILK as a novel therapeutic target for acute and chronic myeloid leukemia. Leuk Res. 2015; pii: S0145-2126(15)30377-5. https://doi.org/10.1016/j.leukres.2015. 09.005. [Epub ahead of print].

52. Wang JP, Hielscher A. Fibronectin: how its aberrant expression in tumors may improve therapeutic targeting. J Cancer. 2017;8:674-82.

53. Williams DA, Rios M, Stephens C, Patel VPFibronectin. and VLA-4 in haematopoietic stem cell-microenvironment interactions. Nature. 1991;352:438-41.

54. Yokota T, Oritani K, Mitsui H, Aoyama K, Ishikawa J, Sugahara $\mathrm{H}$, et al. Growth-supporting activities of fibronectin on hematopoietic stem/progenitor cells in vitro and in vivo: structural requirement for fibronectin activities of CS1 and cell-binding domains. Blood. 1998;91:3263-72.

55. Włodek J, Pituch-Noworolska A. The influence of fibronectin on proliferation and apoptosis of acute lymphoblastic leukaemia cells in vitro. Pol J Pathol. 2018;69:62-6.

56. Graham SM, Jorgensen HG, Allan E, Pearson C, Alcorn MJ, Richmond L, et al. Primitive, quiescent, Philadelphiapositive stem cells from patients with chronic myeloid leukemia are insensitive to STI571 in vitro. Blood. 2002; 99:319-25. 